\begin{tabular}{|c|l|}
\hline Title & Primary productivity, bacterial productivity and nitrogen uptake in response to iron enrichment during the SEEDS II \\
\hline Author(s) & Kudo, Isao; Noiri, Yoshifumi; Cochlan, William P.; Suzuki, Koji; A ramaki, Takafumi; Ono, Tsuneo; Nojiri, Y ukihiro \\
\hline Citation & $\begin{array}{l}\text { Deep Sea Research Part II: Topical Studies in Oceanography, 56(26), 2755-2766 } \\
\text { https://doi.org/40.1016j.dsr2.2009.06.003 }\end{array}$ \\
\hline Issue Date & 2009 -12-15 \\
\hline Doc URL & http://hdl.handle.net/2115/42553 \\
\hline Type & article (author version) \\
\hline File Information & DSR2_56-26_2755-2766.pdf \\
\hline
\end{tabular}

Instructions for use 


\section{Primary Productivity, Bacterial Productivity and Nitrogen Uptake in Response to Iron Enrichment during the SEEDS II}

Isao Kudo ${ }^{a^{*}}$, Yoshifumi Noiri ${ }^{a}$, William P. Cochlan ${ }^{b}$, Koji Suzuki $^{c}$, Takafumi Aramaki ${ }^{d}$, Tsuneo Ono ${ }^{e}$ and Yukihiro Nojiri ${ }^{d}$

${ }^{a}$ Graduate School of Fisheries Sciences, Hokkaido University, Sapporo, Hokkaido 060 0810, Japan

${ }^{b}$ Romberg Tiburon Center for Environmental Studies, San Francisco State University, 3152 Paradise Drive, Tiburon, CA 94920-1205, USA

${ }^{c}$ Faculty of Environmental Earth Science, Hokkaido University, Sapporo, Hokkaido 060 0810, Japan

${ }^{d}$ National Institute for Environmental Studies, Tsukuba, Ibaraki 305-8506, Japan

${ }^{e}$ Hokkaido National Research Institute, Fisheries Research Agency, Kushiro, Hokkaido, 085-0802, Japan

Keywords: Phytoplankton, Heterotrophic bacteria, carbon budget, subarctic Pacific Ocean, Fe enrichment, chlorophyll a

*Corresponding author, Tel. \& fax: +81 117062321

E-mail address: ikudo@fish.hokudai.ac.jp (I. Kudo) 


\section{Abstract}

Primary productivity (PP), bacterial productivity (BP) and the uptake rates of nitrate and ammonium were measured using isotopic methods $\left({ }^{13} \mathrm{C},{ }^{3} \mathrm{H},{ }^{15} \mathrm{~N}\right)$ during a mesoscale iron (Fe)-enrichment experiment conducted in the western subarctic Pacific Ocean in 2004 (SEEDS II). PP increased following Fe enrichment, reached maximal rates 12 days after the enrichment, and then declined to the initial level on day 17. During the 23-d observation period, we observed the development and decline of the Fe-induced bloom. The surface mixed layer (SML) integrated PP increased by 3-fold, but was smaller than the 5-fold increase observed in the previous Fe-enrichment experiment conducted at almost the same location and season during 2001 (SEEDS). Nitrate uptake rates were enhanced by the Fe-enrichment but decreased after day 5, and became lower than ammonium uptake rates after day 17 . The total nitrogenous nutrient uptake rate declined after the peak of the bloom, and accumulation of ammonium was obvious in the euphotic layer. Nitrate utilization accounted for all the requirements of $\mathrm{N}$ for the massive bloom development during SEEDS, whereas during SEEDS II, nitrate accounted for $>90 \%$ of total $\mathrm{N}$ utilization on day 5 , declining to $40 \%$ by the end of the observation period. The SML integrated BP increased after day 2 and peaked twice on day 8 and day 21. Ammonium accumulation and the delayed heterotrophic activity suggested active regeneration occurred after the peak of the bloom. The SML integrated PP between day 0 and day 23 was $19.0 \mathrm{~g} \mathrm{C} \mathrm{m}^{-2}$. The SML integrated BP during the same period was 2.6 g C m$~^{-2}$, which was $14 \%$ of the SML integrated PP. Carbon budget calculation for the whole experimental period indicated that 33\% of the whole (particulate plus dissolved) PP (21.5 g C m${ }^{-2}$ ) was exported below the SML and 18\% was transferred to the meso-zooplankton (growth). The bacterial carbon consumption (43\% of the whole PP) was supported by DOC or POC release from phytoplankton, zooplankton, protozoa and viruses. More than a half (56\%) of the whole PP in the Fe patch was consumed within the SML by respiration of heterotrophic organisms and returned to $\mathrm{CO}_{2}$. 


\section{Introduction}

It has been more than a decade since the first mesoscale Fe enrichment experiment was conducted in the equatorial Pacific Ocean in 1993 (Martin et al., 1994). After this initial experiment, a dozen similarly designed mesoscale experiments were performed in the three major HNLC regions (the equatorial Pacific, Southern Ocean, and subarctic Pacific). All experiments have shown positive algal responses to Fe enrichment, although the extent and magnitude of the resulting algal blooms were dissimilar due to their different physical conditions and ecological components (de Baar et al., 2005). In the subarctic Pacific Ocean, mesoscale experiments were performed in the western (SEEDS) and eastern (SERIES) regions in 2001 and 2002, respectively (Tsuda et al., 2003; Boyd et al., 2004). These two experiments both showed that Fe enrichment stimulates primary productivity and results in an increase in phytoplankton biomass. The SEEDS experiment apparently showed that HNLC water of the western subarctic Pacific Ocean have the highest potential to produce organic carbon following Fe-enrichment (Tsuda et al., 2003). SEEDS was characterized by the highest chlorophyll a concentration achieved, greatest increase in primary productivity, and largest drawdown of macronutrients and dissolved carbon dioxide among the first nine Fe enrichment experiments conducted in the HNLC waters (de Baar et al., 2005). However, two weeks lagrangian observation in the Fe-enriched waters was insufficient to follow the complete bloom trajectory. The SEEDS II experiment in 2004 was conducted at almost the same place and timing of SEEDS, but with a lengthened observational period to follow the complete bloom development and decline phases.

In this study, we examined the phytoplankton response to Fe enrichment by measuring particulate primary productivity, biomass (as chlorophyll $a$ ), and inorganic nitrogen uptake rates (nitrate and ammonium) throughout the experiment. The response of heterotrophic bacterial biomass and productivity were measured to estimate carbon flow through the microbial food web. We have attempted to construct a carbon budget during the experiment by integrating our measured rates of primary productivity with the POC inventory, export flux, zooplankton grazing rates, and heterotrophic bacterial carbon demand.

\section{Materials and methods}

\subsection{General design of Fe enrichment experiment}

Fe- enrichments (with inert tracer $\mathrm{SF}_{6}$, sulfur hexafluoride) were conducted on July 20 (GMT) at $48^{\circ} \mathrm{N}, 166^{\circ} \mathrm{E}$ (day 0 ) and six days later (day 6) during the SEEDS II cruise in the western subarctic Pacific Ocean from July 13 to August 27, 2004 aboard the R.V. Hakuho Maru and R.V. Kilo-Moana. 
Observations and sampling were carried out for a total of 26 days. Samples were collected from both inside the Fe-fertilized patch (hereafter referred to as IN) and at control stations outside the patch (hereafter referred to as OUT). The location of the IN and OUT stations was determined by horizontal surveys of subsurface $(5 \mathrm{~m})$ concentration of $\mathrm{SF}_{6}$ and/or $p \mathrm{CO}_{2}$ measured onboard. The methodology for the actual Fe-enrichment and tracking of the Fe-patch is described by Tsumune et al. (2005). More details of the sampling strategies are described in Tsuda et al. (2007).

\subsection{Primary productivity and nitrogenous nutrient uptake}

Water samples for particulate primary productivity (PP) were collected with Teflon ${ }^{\circledR}$-coated, trace metal clean Niskin X type samplers attached to CTD-CMS from 6 light penetration depths (100, 55, 33, 10, 3 and 1\% of the surface irradiance). The sampling depths were determined from the irradiance profile obtained just before the CTD casts and are listed in Table 1. Surface irradiance $\left(\mathrm{I}_{0}\right)$ was monitored with a $2 \pi$ sensor (ML-020P, Eko Instruments, Hakuho Maru) and a cosine sensor (LI-190SA, LI-COR, Kilo Moana), and underwater irradiance was measured with a PRR-600 (Biospherical Instruments Inc). Water samples were dispensed into acid-cleaned, polycarbonate (Nalgene) bottles $(250 \mathrm{~mL})$ on deck. An aliquot (1\% of total inorganic carbon) of ${ }^{13} \mathrm{C}$-labeled $\mathrm{NaH}^{13} \mathrm{CO}_{3}$ (99 at-\%; Shoko Co., ltd) was added to each bottle within an hour after sampling. Triplicate incubations were conducted for each light depth in deckboard Plexiglas ${ }^{\circledR}$ seawater tanks $\left(100 \% \mathrm{I}_{0}\right)$, or in light attenuated, thermo-controlled (temperature at each depth) tanks (the other light depths) for 24 hours. Light attenuation was achieved using a combination of blue film and black mesh screens. After the incubations, particulates were collected by filtration (pre-combusted Whatman GF/F filters), and the filters were stored in a $-80^{\circ} \mathrm{C}$ deep freezer. The measurement principles, equipment and calculations were described in Hama et al. (1983), and the detailed methodology is outlined by Imai et al. (2002) and Kudo et al. (2005). Depth-integrated particulate primary productivity was calculated by trapezoidal integration of the surface mixed layer (SML) because distribution of enriched Fe and subsequent effect was limited to this layer.

Nitrate and ammonium uptake experiments were conducted in duplicate after inoculation with $1.0 \mu \mathrm{M}{ }^{15} \mathrm{~N}$-potassium nitrate (99.2 atom \%; Shoko Co., Ltd) or $0.1 \mu \mathrm{M}{ }^{15} \mathrm{~N}$-ammonium sulfate (99.6 atom \%; Shoko Co., Ltd), respectively. Sampling and handling were the same as for the primary productivity experiments, but $\mathrm{N}$ uptake measurements only were conducted on samples from the $55 \%$ light penetration depth. Absolute and biomass specific ( $\mathrm{N}$ taken up per unit particulate nitrogen [PN]) uptake rates, estimated from ${ }^{15} \mathrm{~N}$ accumulation in the particulates, were calculated using equations numbered 3 and 5, respectively of Dugdale and Wilkerson (1986); ammonium uptake rates were not corrected for the effects of isotopic dilution, and thus are likely underestimates 
of the true ammonium uptake rates (Glibert et al., 1982). We also have not estimated potential losses of ${ }^{15} \mathrm{~N}$ to the DON pool (Bronk et al., 1994). The ratio of nitrate uptake to total nitrogen (nitrate and ammonium) uptake, termed the f-ratio (Eppley and Peterson, 1979), is used to estimate 'new' and 'regenerated' production (Dugdale and Goering, 1967). The isotopic enrichment of carbon and nitrogen were measured with an ANCA-SL Stable Isotope Analysis System (Europa Scientific). Triplicate samples were analyzed for $\mathrm{C}$, and the $\mathrm{N}$ analysis was conducted on one of the duplicate samples.

Unfiltered samples for nutrient analysis were stored frozen at $-30^{\circ} \mathrm{C}$. Nutrients were measured in duplicate with a TRAACS 800 Analyzer (Bran-Luebbe). Total chlorophyll- $a$ (Chl- $a$ ) concentration was determined using non-acidification, in vitro fluorometric analyses (Welshmeyer (1994) after filtration onto Whatman GF/F filters $(0.7-\mu \mathrm{m})$. Size-fractionated biomass was determined by filtration of $500 \mathrm{~mL}$ of seawater onto Nuclepore polycarbonate filters (10, 2 and $0.2 \mu \mathrm{m}$ pore size). Samples were extracted in $N,-N$, dimethylformamide (DMF) for ca. 24 hours $\left(-20^{\circ} \mathrm{C}\right)$, and fluorescence was measured with Turner Designs 10AU fluorometers calibrated at the beginning of each cruise with pure chlorophyll $a$ (Suzuki and Ishimaru, 1990). The definitions for the size fractions were as follows: micro-sized (retained on a $10 \mu \mathrm{m}$ filter), nano-sized (passing through $10 \mu \mathrm{m}$ filter but retained by 2 $\mu \mathrm{m}$ filter), and pico-sized (passing through $2 \mu \mathrm{m}$ filter but retained on $0.2 \mu \mathrm{m}$ filter).

\subsection{Bacterial productivity and abundance}

Water samples for bacterial productivity were collected as previously described for PP, but only from 2 light depths (55 and 10\%) were sampled during day 14 and day 21. Bacterial productivity was estimated measuring ${ }^{3} \mathrm{H}$-leucine uptake to bacterial protein (Kirchman et al., 1985, Simon and Azam, 1989). Triplicate water samples (10 mL) were dispensed into sterile polystyrene test tubes,

${ }^{3} \mathrm{H}$-labeled leucine added at a final concentration of $20 \mathrm{nM}$, and samples incubated in the dark at simulated in situ temperatures for $6 \mathrm{~h}$. Incubations were terminated by the addition of $500 \mu \mathrm{L}$ of $100 \%$ TCA (trichloroacetic acid). Particulate matter was collected on $0.22-\mu \mathrm{m}$ cellulose Millipore filters, rinsed twice with $2 \mathrm{~mL}$ of ice-cold 5\% TCA for 2-3 min, and further rinsed with ice-cold $80 \%$ ethanol. Filters were placed into $10 \mathrm{~mL}$ liquid scintillation vials containing scintillation cocktail (Ultima Gold AB, Parkin Elmer) and counted with a Wallec 1414 liquid scintillation counter. Bacterial productivity was calculated using the standard conversion factors (Simon and Azam, 1989). Blank correction was made by duplicate TCA-killed (final conc. 5\%) samples. Relative standard deviation (CV) for triplicate measurements was generally less than $5 \%$.

Bacterial abundance was obtained following the method of Suzuki et al. (2005). Duplicate water samples $(2 \mathrm{~mL})$ were preserved with paraformaldehyde ( $0.2 \%$ final concentration), and stored in a deep-freezer at $-80^{\circ} \mathrm{C}$ or in liquid nitrogen until analysis on land. A flow cytometer (FCM; 
EPICS XL ADC, Beckman Coulter) equipped with a $15 \mathrm{~mW}$ air-cooled laser exciting at $488 \mathrm{~nm}$ and the standard filter setup was used to enumerate heterotrophic bacteria. Prior to analysis, samples were thawed, and then drawn through 35- $\mu$ m nylon mesh-capped Falcon cell strainer (Becton-Dickinson) to remove larger cells. Cells were stained with the nucleic acid stain SYBR Green I (Marie et al., 1997). Working stocks of SYBR Green I ( $10^{-3}$ of the commercial solution, Molecular Probes) were freshly prepared on the day of analysis, and $10 \%$ of the working stock was added to sub-samples, and incubated in the dark at room temperature $\left(25^{\circ} \mathrm{C}\right)$ for $30 \mathrm{~min}$ before analysis. The incubated samples were mixed with a certain volume of Flow-Count fluorospheres (Beckman Coulter), a fluorescent microsphere reagent for determining the cell concentration of the samples, and the concentration of the beads was determined by the manufacturer, and then analyzed. The Fluoresbrite YG beads (Poly Sciences) of 0.5 and $2 \mu \mathrm{m}$ in diameter were used separately from the samples for estimating an approximate estimate of cell size under the same FCM setting.

Depth-integrated bacterial productivity and abundance was calculated by trapezoidal integration of the surface mixed layer (SML). In case the sampling depth for bacterial productivity was shallower than the SML (from day 14 to 21), the value for the bottom of SML was estimated from the profiles of contiguous days because of a smaller variation in this layer.

\section{Results}

\subsection{Physical conditions}

Temperature and salinity at surface on the day of Fe enrichment (day 0) was $8.3^{\circ} \mathrm{C}$ and 32.93 , respectively and vertically homogeneous to $20 \mathrm{~m}$ (Figs. 1A,B). The surface temperature increased gradually and was $11.9^{\circ} \mathrm{C}$ on day 25. The surface salinity decreased after day 9 from 32.86 to 32.84 on day 25. The surface mixed layer (SML) depth, defined as the depth within 0.2 difference of sigma- $t$ at the surface, was $20 \mathrm{~m}$ on day 0 and deepened to $34 \mathrm{~m}$ on day 8 , but shallowed to $20 \mathrm{~m}$ on day 10 (Fig. 1). The SML depth varied between 20 and $34 \mathrm{~m}$ until day 17, but was $12 \mathrm{~m}$ on day 25. Daily photon flux fluctuated between 10 and $58 \mathrm{E} \mathrm{m}^{-2} \mathrm{~d}^{-1}$ depending on degree of cloud cover (Saito et al., this issue). The euphotic layer, defined as $1 \%$ of the surface irradiance, was $41 \mathrm{~m}$ on day 0 , shallowed to $25 \mathrm{~m}$ by day 8 , remained relatively constant (averaging $35 \mathrm{~m}$ ) until day 25 before deepening to $46 \mathrm{~m}$ on day 25 (Table 1). The mean euphotic layer depth of the outside was $43 \mathrm{~m}$ (ranging from 38 to $46 \mathrm{~m}$ ).

\subsection{Nutrients and Chl a}

Prior to Fe enrichment, the ambient concentrations of nitrate, silicic acid and phosphate at $5 \mathrm{~m}$ were abundant: 18.5, 38.5 and $1.61 \mu \mathrm{M}$, respectively (Figs. 1C and 2). The concentrations of nitrate, silicic acid and phosphate in the IN-patch decreased relatively linearly, and were 13.9, 34.7 and 1.44 $\mu \mathrm{M}$ on day 23, respectively. The concentrations of these nutrients within the SML were very similar 
to those at $5 \mathrm{~m}$ (e.g., nitrate: Fig. 1C). Nitrate, silicic acid and phosphate also decreased gradually in the OUT-patch on day 23 to 16.3, 34.3 and $1.53 \mu \mathrm{M}$, respectively. The net decrease in the IN-patch (difference between IN- and OUT-patch) between day 0 and day 23 was 2.4, -0.4 and $0.09 \mu \mathrm{M}$ for nitrate, silicic acid and phosphate, respectively. The ambient concentration of ammonium was low $(0.1 \mu \mathrm{M})$ at $5 \mathrm{~m}$ for the first 2 weeks after Fe enrichment, but increased up to $0.5 \mu \mathrm{M}$ on day 21 (Fig. 1D). The ammonium inventory between 0 and $20 \mathrm{~m}$ in the IN-patch was relatively constant until day 13, increased three fold on day 14 and was highest at $10 \mathrm{mmol} \mathrm{m}^{-2}$ on day 21 (Fig 3). A steady increase in ammonium was observed below the SML although there was some fluctuation. The concentration of ammonium at $30 \mathrm{~m}$ was $1.2 \mu \mathrm{M}$ on day 25 , with net increase of $0.7 \mu \mathrm{M}$ during the observation period. More details on nutrient dynamics are described in Saito et al. (this issue).

Mean Chl- $a$ concentration in the SML was $0.8 \mathrm{mg} \mathrm{m}^{-3}$ on day 0 , increased gradually over the next 10-12 days, and reached a maximum of $3.0 \mathrm{mg} \mathrm{m}^{-3}$ at $2 \mathrm{~m}$ on day 11 (Fig. 1E). After the peak, it decreased and returned to the initial Chl- $a$ concentration $<1 \mathrm{mg} \mathrm{m}^{-3}$. High Chl- $a$ concentrations $>2.0$ $\mathrm{mg} \mathrm{m}^{-3}$ were observed between days 5 and 16 within the SML.

Nanoplankton-sized $(2-10 \mu \mathrm{m})$ Chl- $a$ dominated the phytoplankton assemblage $(47.7 \%$ of the total Chl- $a$ ) on day 0 at $5 \mathrm{~m}$, followed by the picoplankon-sized $(0.2-2 \mu \mathrm{m})$ fraction $(25.3 \%$ of the total Chl-a; Fig. 4). Following Fe enrichment, Chl-a concentrations increased with time in all size-fractions measured, but the relative proportions of each size fraction to the total biomass did not change substantially during the development of the bloom (day 2 to 8). At the peak of total Chl- $a$ at $5 \mathrm{~m}$ on day 10, the relative proportion of nano-, pico- and micro-sized plankton was $41.3,35.8$ and 23.9\%, respectively (Fig. 4B). Then, the contribution of picoplankton-sized Chl- $a$ increased and that of microplankton-sized Chl- $a$ gradually decreased.

\subsection{Primary productivity}

Particulate primary productivity on day 0 was $15-25 \mathrm{mg} \mathrm{C} \mathrm{m}^{-3} \mathrm{~d}^{-1}$ in the surface mixed layer (Fig. 1F). A 2-fold increase was observed after day 4 (50 $\mathrm{mg} \mathrm{C} \mathrm{m}^{-3} \mathrm{~d}^{-1}$ at $\left.3 \mathrm{~m}\right)$, and the maximum rate of $110 \mathrm{mg} \mathrm{C} \mathrm{m}^{-3} \mathrm{~d}^{-1}$ was observed at $2 \mathrm{~m}$ on day 10 , which was four times greater than the initial PP at this depth. The high PP rates measured at the surface ( $>100 \mathrm{mg} \mathrm{C} \mathrm{m}^{-3} \mathrm{~d}^{-1}$ ) continued until day 11, and decreased gradually. After day 17, PP rates in the SML (Fe patch) were the same as those observed on day 0. Similar increases in PP following Fe enrichment were not observed below the SML, where PP increased by only $<20 \mathrm{mg} \mathrm{C} \mathrm{m}^{-3} \mathrm{~d}^{-1}$. The SML integrated PP was $0.39 \mathrm{~g} \mathrm{C} \mathrm{m}^{-2} \mathrm{~d}^{-1}$ on day 0 , increased rapidly after day 2 and peaked during day 5 and day 11 at $>1.0 \mathrm{~g} \mathrm{C} \mathrm{m}^{-2} \mathrm{~d}^{-1}$ (Fig. 5). The SML integrated PP decreased to the initial value on day 17 and remained constant until the end of the observation. Outside the patch, the SML integrated PP increased on day $11\left(0.72 \mathrm{~g} \mathrm{C} \mathrm{m}^{-2} \mathrm{~d}^{-1}\right)$, and decreased to the initial value afterward (Fig. 5). The SML integrated PP summed for the entire 
observation period (23 days) was 19.0 and $12.2 \mathrm{~g} \mathrm{C} \mathrm{m}^{-2}$ for IN-patch and OUT-patches, respectively (integration period for OUT-patch was adjusted from 24 to 23 days).

\section{$3.4 N$ uptake}

The PN specific uptake rate of $\mathrm{NO}_{3}$ at $55 \% \mathrm{I}_{0}$ inside the Fe patch (Fig. 6A) was $0.0016 \mathrm{~h}^{-1}$ on day 0 , increased 10 -fold to $0.016 \mathrm{~h}^{-1}$ by day 5 , and then gradually decreased to the initial rate on day 23. The PN specific $\mathrm{NH}_{4}$-uptake rates varied from 0.0007 to $0.0026 \mathrm{~h}^{-1}$ for the first 10 days, and then increased to $0.0047 \mathrm{~h}^{-1}$ on day 16 and 23. The absolute uptake rate of nitrate on day 0 was 0.0065 $\mu \mathrm{M} \mathrm{h}^{-1}$ (Fig. 6B). It increased to $0.06 \mu \mathrm{M} \mathrm{h}^{-1}$ on day 5 , then decreased gradually and returned to the initial rate by day 23. The absolute uptake rate of ammonium was $\sim 0.01 \mu \mathrm{M} \mathrm{h}^{-1}$ until day 5 and then increased up to $0.017 \mu \mathrm{M} \mathrm{h}^{-1}$ on day 17 when the uptake rate of ammonium was greater than that of nitrate. The uptake rate of nitrate and ammonium outside the Fe patch did not change throughout the observation (data not shown). The $f$-ratio was $\sim 0.7$ at the beginning the Fe-experiment, increased to $>0.8$ on day 5 and 11(Fig. 7), before declining to $\sim 0.4-0.5$ by day 17 and subsequent sampling dates. The $f$-ratio in the OUT-patch ranged from 0.5 to 0.6

\subsection{Heterotrophic bacterial biomass and productivity}

The abundance of heterotrophic bacteria (BA) was $\sim 1 \times 10^{11}$ cells $\mathrm{m}^{-3}$ on day 0 and distributed almost homogeneously throughout the surface mixed layer (Fig. 1G). BA increased after Fe enrichment, and peaked on day 14 at $4 \times 10^{11}$ cells $\mathrm{m}^{-3}$; a four-fold increase. It decreased to $2 \times 10^{11}$ cells $\mathrm{m}^{-3}$ on day 19 and increased again to $3 \times 10^{11}$ cells $\mathrm{m}^{-3}$ on day 21-23. BA below the surface mixed layer was less than $1 \times 10^{11}$ cells $\mathrm{m}^{-3}$ until day 20, but increased slightly up to $2 \times 10^{11}$ cells $^{-3}$ between day 20 and 25. Bacterial productivity (BP) in the SML of the IN-patch was $4 \mathrm{mg} \mathrm{C} \mathrm{m}^{-3} \mathrm{~d}^{-1}$ on day 0 , and increased from day 4 to 7-8 $\mathrm{mg} \mathrm{C} \mathrm{m}^{-3} \mathrm{~d}^{-1}$ and remained constant until day 12 (Fig. $1 \mathrm{H}$ ). Then, BP subsequently declined to $3.3 \mathrm{mg} \mathrm{C} \mathrm{m}^{-3} \mathrm{~d}^{-1}$ on day 17 , but increased again to $8 \mathrm{mg} \mathrm{C} \mathrm{m}^{-3} \mathrm{~d}^{-1}$ on day 23. The SML integrated BA showed higher values after day 8 relative to the OUT-patch (Fig. 8). This value dropped to the same value to the OUT-patch on day 18 and rose again on day 23. The SML integrated BP increased after day 5 compared with the OUT-patch (Fig. 8). This value decreased after day 8 to the same value to the OUT-patch on day 17 and increased again on day 21.

\section{Discussion}

\subsection{Enhancement of $C$ and $N$ uptake by Fe enrichment}

Particulate primary productivity was enhanced after Fe enrichment, and the SML integrated PP (day 0-23) in the IN-patch $\left(19.0 \mathrm{~g} \mathrm{C} \mathrm{m}^{-2}\right)$ was 1.6-fold greater than that in the OUT-patch $(12.2 \mathrm{~g} \mathrm{C}$ $\mathrm{m}^{-2}$ ) during this study. The maximum concentration of Chl- $a$ in the IN-patch was $3.0 \mathrm{mg} \mathrm{m}^{-3}$ (day 11, $2 \mathrm{~m}$ ) while Chl- $a$ on the same day in the OUT-patch was $<1.0 \mathrm{mg} \mathrm{m}^{-3}$. Chl- $a$ specific primary productivity (i.e., assimilation number) at 55\% $\mathrm{I}_{0}$ was greater in the IN-patch until day 10 than 
observed in the OUT-patch (Fig. 9) although there were no differences after day 10. This indicates that the increase in PP for the first 10 days was not merely a function of the increased biomass, however by day 12 the assimilation numbers in both patches were similar, so the maximum difference in the integrated PP on day 12 between IN and OUT patches reflects the difference in the phytoplankton biomass. Higher assimilation numbers in both patches were observed at the end of the observation. This seemed the adaptation effect to an increase in daily PAR flux after day 20, resulting in a decrease of cellular photosynthetic pigments (Falkowski and Raven, 1997).

The absolute uptake rate of nitrate increased 4.3-fold from days 2 to 5 (Fig. 6). The PN specific uptake rate of nitrate also increased by a factor of 4 in the IN-patch during the same period, indicating that the enhancement of nitrate uptake was not due to the accumulation of phytoplankton biomass, but the increase in nitrate uptake rate per phytoplankton biomass. Similar results of enhanced biomass-specific $\mathrm{NO}_{3}$ uptake rates have been observed following iron enrichment during previous mesoscale Fe experiments in the equatorial Pacific (IronEx II: Coale et al., 1996; Cochlan 2001), Southern Ocean (SOFeX: Coale et al., 2004; Cochlan and Kudela, 2006), and the western (SEEDS: Kudo et al., 2005) and eastern (SERIES: Marchetti et al., 2006a) subarctic Pacific Ocean, as well as during deckboard bottle experiments in the Southern Ocean: (Timmermans et al., 1998; Cochlan et al., 2002), equatorial Pacific (Price et al., 1991, 1994), and eastern subarctic Pacific Ocean (Boyd et al., 1996). These results suggest that prior to Fe enrichment, the nitrate assimilation processes were likely limited by low availability of Fe since two metalloenzymes necessary for assimilating nitrate (nitrate reductase and nitrite reductase), require $\mathrm{Fe}$ for their functioning (e.g., Timmermans et al., 1994, Kudo et al., 2000, Milligan and Harrison, 2000).

The increase in both ambient ammonium concentration (Fig. 3) and $\mathrm{PN}$-specific $\mathrm{NH}_{4}$ uptake rates (Fig. 6A) were evident in the latter half of the observation period, presumably due to enhanced regeneration activities, and the resultant concentration-dependent affects on $\mathrm{NH}_{4}$ uptake rate (e.g., Cochlan and Bronk, 2001). These results are in contrast with others who generally have reported no substantial increase in specific $\mathrm{NH}_{4}$ uptake rates following Fe enrichment of HNLC waters (Price et al., 1991, 1994; Boyd et al., 1996; Cochlan and Kudela, 1996; Timmermans et al., 1998; Cochlan et al., 2002). In SEEDS, most of the in situ $\mathrm{N}$ requirements were supported by nitrate uptake and the $f$-ratio (contribution of nitrate uptake to the total $\mathrm{N}$ uptake) was very high (>0.9) from days 7 to 13 (Kudo et al., 2005). During SEEDS II, the $f$-ratio increased from 0.6 to 0.9 by day 5, but decreased to 0.8 on days 8 and 12, and to 0.4 by day 17 (Fig. 7). One of the reasons for the difference in nitrogenous nutrition during these two experiments is the difference in the duration of that the fertilized Fe remained available for phytoplankton utilization. The decrease of dissolved Fe concentration after Fe-enrichment was much faster in SEEDS II than in SEEDS (Tsuda et al., 2007). 
A second Fe addition on day 6 in SEEDS II was required to maintain dissolved Fe concentration at higher than $0.5 \mathrm{nM}$. However, dissolved Fe concentration decreased to the same level as in the OUT-patch after day 10.

The total new production for 23 days was calculated as $13.5 \mathrm{~g} \mathrm{C} \mathrm{m}^{-2}$, integrating the daily new production estimate from the PP and f-ratio for each day. This estimate was consistent with the new production based on the nitrate drawdown in the IN-patch (Saito et al., this issue). This new production was $71 \%$ of the total PP, thus overall $f$-ratio was 0.71 .

Another point to consider with respect to nitrogenous nutrition in the subarctic Pacific Ocean is their differing background conditions under 'normal' non Fe-amended conditions. During both SEEDS and SEEDS II, the $f$-ratios in the OUT-patches were $\sim 0.6$ whereas in SERIES this ratio was only 0.2-0.4 (Kudo unpublished), and this may reflect a difference in Fe supply between western and eastern subarctic Pacific Ocean.

The maximum Chl- $a$ concentrations achieved among the three mesoscale Fe enrichment experiments in the subarctic Pacific Ocean follow the order; SEEDS in 2001: $17.0 \mathrm{mg} \mathrm{m}^{-3}$ (Tsuda et al., 2003), SERIES in 2002: $8.5 \mathrm{mg} \mathrm{m}^{-3}$ (Boyd et al., 2004) and SEEDS II in 2004: $3.0 \mathrm{mg} \mathrm{m}^{-3}$. The same order was obtained in the maximum primary productivity, $310 \mathrm{mg} \mathrm{C} \mathrm{m}^{-3} \mathrm{~d}^{-1}$ during SEEDS (Kudo et al., 2005), $180 \mathrm{mg} \mathrm{C} \mathrm{m}^{-3} \mathrm{~d}^{-1}$ during SERIES (Marchetti et al., 2006b) and $112 \mathrm{mg} \mathrm{C} \mathrm{m}^{-3} \mathrm{~d}^{-1}$ in SEEDS II (this study). The SEEDS II experiment was conducted at almost the same place and timing as SEEDS, however, a substantially different algal response was observed (Tsuda et al., 2007). One of the possible explanations for the lower algal biomass was high grazing pressure by meso-zooplankton on diatoms (Saito et al., this issue; Tsuda et al., this issue). Micro-sized phytoplankton (mainly diatoms) composed only $30 \%$ of total Chl- $a$, but decreased to $<20 \%$ at the end of the observation period (Fig. 4). Another explanation was a lack of fast-growing neritic diatoms following Fe addition such as Chaetoceros debilis found in SEEDS (Tsuda et al., 2003), although some oceanic diatom species such as Pseudo-nitzschia spp. and Neodenticula seminae increased in the Fe patch during SEEDS II (Tsuda et al., 2007).

In contrast, the time required to attain maximal biomass concentrations was shorter in SEEDS and SEEDS II than in SERIES; 15-18 days in SERIES, 8-12 days in SEEDS and 11 days in SEEDS II. In SEEDS II, the SML integrated PP (Fig. 6) and assimilation number (Fig. 9) increased after day 2. Noiri et al. (2005) and Kudo et al. (2006) conducted deckboard, Fe-addition bottle incubation experiments during SEEDS and SERIES by varying the ambient Fe concentrations and reported a 1.8-fold greater maximum growth rate for micro-sized phytoplankton community in the western subarctic Pacific (SEEDS) compared to the eastern subarctic Pacific (SERIES). Mesoscale Fe enrichment experiments generally increase $\mathrm{Fe}$ concentration to $>2 \mathrm{nM}$, thus a comparison of 
maximum growth rate achieved with saturated concentrations may indicate the difference in the initial response of phytoplankton community to Fe enrichment experiments. These results suggested the rapid response of phytoplankton to Fe enrichment in the western subarctic Pacific compared with the eastern subarctic Pacific was due to the difference in the maximum growth rate of phytoplankton community under the saturated Fe concentration.

\subsection{Heterotrophic bacterial response to Fe enrichment}

BA was initially $1.5-2.0 \times 10^{11}$ cells $\mathrm{m}^{-3}$, did not change in the OUT-patch, but increased 2.7-fold by day 14 in the IN-patch during SEEDS II. A similar 2.5-fold increase in BA was observed during SEEDS following Fe enrichment (Suzuki et al., 2005). While total BP in SEEDS II showed 1.6-fold increase in the IN-patch relative to the OUT-patch, comparison of BP between the two experiments is not possible (no BP measurement in SEEDS).

Heterotrophic bacteria may compete for Fe with phytoplankton when Fe resources are limited because they have a higher requirement of Fe (relative to C) than phytoplankton (e.g., Maldonado and Price, 1999). However, the increase in BP occurred 3-5 days after the increase in PP. Generally heterotrophic bacterial growth is considered limited by substrate availability (DOM) in the open ocean (Kirchman et al., 1993, Kirchman and Rich, 1997). The major source of this substrate is phytoplankton either from direct exudation, passive release, or cell breakage during zooplankton grazing or viral lysis. Thus the increase in BP after Fe enrichment seemed the result of increased DOM supply by the acceleration of PP. This explanation is consistent with that presented for other HNLC areas, where heterotrophic bacterial growth is apparently limited more by the availability of DOM, not Fe (Church et al., 2000; Kirchman et al., 2000; Cochlan, 2001; Hall and Safi, 2001; Hale et al., 2006). However, no obvious increase in DOC concentrations were found in the IN-patch during SEEDS II (Yoshimura et al., this issue), possibly due to the labile nature of phytoplankton-derived DOC, and the preferential (and immediate) use by heterotrophic bacteria (Norrman et al., 1995; Meon and Kirchman, 2001).

A comparison of the vertical profiles of PP and BP (Figs $1 \mathrm{~F}$ and $\mathrm{H}$ ) shows that PP decreased exponentially in response to the attenuation of light with depth whereas elevated BP was observed near the bottom of SML (day 7-12), suggesting that mixing processes distributed bacterial substrate uniformly within this layer. It is worth mentioning that BP increased again after day 20 when copepod biomass peaked (Tsuda et al. 2007), suggesting an acceleration of DOM release through active copepod ingestion.

To examine the microbial loop as a pathway for organic material in marine systems bacterial to primary productivity ratio (BP:PP) was often referred (Anderson and Ducklow, 2001). The ratio of SML-integrated BP to PP in the IN-patch was 0.28 on day 0, but decreased to 0.1-0.15 from day 2 to 
17, indicating the increase in PP was much larger relative to that in BP, but increased to 0.27 on day 23. These ratios were higher than the range reported during SERIES (Hale et al., 2006); 0.1 from days 2 to 17 . The ratio in the OUT-patch ranged from 0.10 to 0.19 during the observation period. This range of BP:PP in the present study was similar to the value reported in the subarctic Pacific Ocean (Anderson and Ducklow, 2001). Given that heterotrophic bacteria require organic carbon for both growth (biomass production) and metabolism (i.e., respiration), in order to determine the organic carbon requirements of heterotrophic bacteria it is necessary to know bacterial growth efficiency (BGE) of the assemblage (del Giorgio, 2000) defined as follows,

$\mathrm{BGE}=\mathrm{BP} /(\mathrm{BP}+\mathrm{R})$ or $\mathrm{BP} / \mathrm{BCD}$

where R and BCD are respiration and bacterial carbon demand, respectively.

The BGE values vary widely, ranging from 10 to $30 \%$ for open ocean and coastal areas, respectively (del Giorgio, 2000), but Fe enrichment induces an increase in primary productivity and phytoplankton biomass concentrations to those from open ocean to values typically found in coastal regions. Quantifying the flux of carbon into bacteria is dependent on the accuracy of the BGE, while in this case BGE is unlikely to be constant and independent of growth rate, nutrient limitation or carbon source. Hale et al. (2006) estimated BGE for the IN-patch during SERIES as 24 to $26 \%$ using a temperature dependent equation (Rivkin and Legendre, 2001), and using this equation, BGEs for the IN-patch of SEEDS-II are 27-29\%. Sherry et al. (1999) reported BGE of 37\% for the summer bacterial community in the subarctic Pacific Ocean (Stn. P). In the further calculation, we used BGE as $30 \%$.

The SML integrated BCD was $370 \mathrm{mg} \mathrm{C} \mathrm{m}^{-2}$ on day 0 , increased after day 2 and peaked on day 8 at $629 \mathrm{mg} \mathrm{C} \mathrm{m}^{-2}$ (Fig. 10). The BCD decreased to the same level as that observed in outside waters on day 17. The ratio of depth-integrated BCD:PP was 0.48 on day 2, decreased to 0.37 on day 11 (when PP reached the maximum), and then increased to 0.52 on day 17. The integrated BCD was summed for the entire observation period (23 days), resulting in 8.9 and $6.3 \mathrm{~g} \mathrm{C} \mathrm{m}^{-2}$ for IN- and OUT-patches, respectively. Thus, the ratio of depth-integrated BCD:PP for the whole period in the IN-patch (day 0-23) was 0.47 and similar to that estimated for the OUT-patch (0.52).

\subsection{Efficiency of biological pump}

The SML-integrated PP was summed for 23 days (from days 0 to 23) as 19.0 and $12.2 \mathrm{~g} \mathrm{C} \mathrm{m}^{-2}$ for the IN- and OUT-patches, respectively. During the same period, the POC settling flux obtained from a floating sediment trap at $40 \mathrm{~m}$ was 9.3 and $8.2 \mathrm{~g} \mathrm{C} \mathrm{m}^{-2}$ for the IN- and OUT-patches, (Tsuda et al., 2007, Aramaki et al., this issue). The export ratio (e-ratio: the ratio of exported production to particulate primary productivity) was calculated as 0.49 and 0.67 for the IN-patch and OUT-patch, respectively. This ratio was reported as 0.18 in SERIES (Boyd et al., 2004) based on a sediment trap 
at $50 \mathrm{~m}$ and the decrease in POC inventory after the peak of the diatom bloom (Day 18). Boyd et al. (2004) also reported a maximum estimate of this ratio as 0.22 , considering a trapping efficiency of $76 \%$. The $e$-ratio in this study was more than two times greater than those estimated during SERIES, suggesting a more efficient biological pump in the western subarctic Pacific Ocean. Fe enrichment in the HNLC waters is anticipated to sequester $\mathrm{CO}_{2}$ to the deeper layer by means of accelerating primary productivity in the surface water and consequently increasing sinking flux of organic carbon to the deeper layer (biological pump). It is noteworthy that during SEEDS-II, the efficiency of the biological pump (e-ratio) did not change as a result of Fe enrichment although POC flux increased in the Fe-fertilized patch relative to the outside, unenriched waters. High $e$-ratios of $\sim 0.5$ in the northwest subarctic Pacific Ocean in summer also have been recently reported (Kawakami and Honda, 2007).

Ontogenetic vertical migration of copepod was observed at the end of observation (Tsuda et al., 2007) and the amount of this migration flux was estimated as $89.2 \%$ of the net growth of copepod (Saito et al., this issue). This flux was not included in the export flux measured by the floating sediment trap because trapped copepods were removed as swimmers (Aramaki et al., this issue). Thus, actual export ratio seemed higher than 0.49 , which was estimated by sediment trap flux.

\subsection{Fate of organic carbon production}

As Fe-induced increases in Chl- $a$ and PP returned to their initial levels by day 23 (Fig. 5 \& 6), carbon budget calculations were determined between days 0 and day 23 (Fig. 11). The budget calculation was made within the SML because the distribution of infused Fe was limited to this layer. In our calculations we employed the following values measured or estimated during the observation period: integrated particulate PP (19.0 g C m $)$, net POC inventory decrease $\left(1.5 \mathrm{~g} \mathrm{C} \mathrm{m}^{-2}\right)$, BP (2.7 g $\mathrm{C} \mathrm{m}^{-2}$ ) and BCD $\left(8.9 \mathrm{~g} \mathrm{C} \mathrm{m}^{-2}\right)$. Total ingestion of meso-zooplankton was estimated as $9.8 \mathrm{~g} \mathrm{C} \mathrm{m}^{-2}$, from integrated copepod biomass (Tsuda et al., 2007) and a ratio of daily ingestion to biomass (0.31; Tsuda et al., 2005). Additionally the contribution of PP by smaller phytoplankton (nano- and picoplankton-sized) was estimated as follows; given that the growth rate of small phytoplankton at 5 m was $\sim 0.3 \mathrm{~d}^{-1}$ and was almost balanced by protozoan grazing (estimated by dilution experiments on board; Tsuda et al., this issue), and assuming a C:Chl- $a$ ratio of 50 (Montagnes et al., 1994), one can estimate carbon production based on Chl- $a$ and growth rate. Using these assumptions, PP by smaller phytoplankton at $5 \mathrm{~m}$ depth was $30 \mathrm{mg} \mathrm{C} \mathrm{m}^{-3} \mathrm{~d}^{-1}$ from days 10 to 12 , and $15 \mathrm{mg} \mathrm{C} \mathrm{m}^{-3} \mathrm{~d}^{-1}$ before day 9 and after day 13, and accounted for 33 and $50 \%$ of the total PP. So we assumed $42 \%$ of the measured particulate PP $\left(8.0 \mathrm{~g} \mathrm{C} \mathrm{m}^{-2}\right)$, was carried out by smaller phytoplankton. Thus, the rest (11.0 $\mathrm{g} \mathrm{C} \mathrm{m}^{-2}$ ) was produced by large phytoplankton (microplankton-sized). The percent extracellular release (PER), a fraction of DOM released relative to the whole (dissolved plus particulate) primary 
productivity, ranges from 10 to 20\% in typical marine environments (Baines and Pace, 1991) although it varies greatly depending on physiological state of phytoplankton (Nagata, 2000). In this calculation, we considered PER to be $13 \%$ of particulate PP for calculating the whole PP. The whole (dissolved + particulate) PP for 23 days was estimated as $21.5 \mathrm{~g} \mathrm{C} \mathrm{m}^{-2}$. The whole primary productivity of $21.5 \mathrm{~g} \mathrm{C} \mathrm{m}^{-2}$ was divided into 12.4 and $8.8 \mathrm{~g} \mathrm{C} \mathrm{m}^{-2}$ for the large and small phytoplankton productivity. For the budget calculation following literature values were used; Protozoan gross growth efficiency is $40 \%$ (Caron and Goldman 1990), DOC release is $30 \%$ of ingestion (Strom et al., 1997), meso-zooplankton gross growth efficiency is $40 \%$, and DOC release and fecal pellet production are 22 and 18\% of ingestion (Copping and Lorenzen 1980; Nagata, 2000; Strom et al. 1977; White and Roman 1992). BP is assigned equally to protozoa and virus consumption (Nagata, 2000).

Meso-zooplankton ingestion ( $9.8 \mathrm{~g} \mathrm{C} \mathrm{m}^{-2}$ ) was accounted for $45 \%$ of the whole PP, but some of them were released as DOC or POC, fueling bacterial production (Fig. 11). The net growth of meso-zoolankton ( $3.9 \mathrm{~g} \mathrm{C} \mathrm{m}^{-2}$ ) was $18 \%$ of the whole PP. The bacterial carbon demand of $8.9 \mathrm{~g} \mathrm{C}$ $\mathrm{m}^{-2}$ was accounted for $41 \%$ of the whole PP and supported by DOC or POC release from phytoplankton (28\%), meso-zooplankton (25\%), protozoa (31\%) and viruses (16\%). More than a half $\left(56 \%, 12.1 \mathrm{~g} \mathrm{C} \mathrm{m}^{-2}\right.$ ) of the whole PP was returned to $\mathrm{CO}_{2}$ within the SML (Fe patch) through respiration by heterotrophic organisms (bacteria, protozoa and meso-zooplankton).

Almost all inputs and outputs in each compartment were matched in the budget calculation. However, there were two discrepancies between our observations and calculations: meso-zooplankton growth and export. The difference in meso-zooplankton growth between the budget calculation and another estimate (Tsuda et al., this issue) was $1.4 \mathrm{~g} \mathrm{C} \mathrm{m}^{-2}$. The difference between the budget and sediment trap measurement in export flux was $2.3 \mathrm{~g} \mathrm{C} \mathrm{m}^{-2}$, equivalent to $25 \%$ of the actual export flux. The actual export flux $\left(9.3 \mathrm{~g} \mathrm{C} \mathrm{m}^{-2}\right)$ was $43 \%$ of the whole PP while it was $33 \%\left(7.0 \mathrm{~g} \mathrm{C} \mathrm{m}^{-2}\right)$ in the budget calculation. Some of the estimates in this budget calculation may accompany certain errors because no measurements were made for some of the parameters required during the experiment. However, this is the estimate of carbon budget including the most detailed ecological processes in the Fe fertilization experiments.

The SEEDS II experiment was conducted during a time of elevated biomass of the meso-zooplankton, Neocalanus plumchrus, leading to a high C flow to meso-zooplankton (Tsuda et al, 2007). It would seem interesting to plan any additional Fe enrichment experiment when lower meso-zooplankton biomass is expected to elucidate the contribution of meso-zooplankton to the efficiency of biological pump.

\section{Conclusions}


The second Fe enrichment experiment (SEEDS II) conducted in the western subarctic Pacific Ocean in the summer 2004 resulted in lower phytoplankton productivity and biomass than observed during the previous Fe experiment (SEEDS) conducted in the same region and season during 2001. Following Fe-enrichment, phytoplankton growth was initially enhanced by increased nitrate uptake (biomass-specific uptake rates increased 10 fold during the first 5 days), but by day 17 ammonium uptake dominated phytoplankton nitrogenous nutrition. Particulate PP increased on day 2 and peaked during day 5 and day 11, but after day 17 PP did not differ from the OUT-patch. The total particulate PP for 23 days of observation $\left(19.0 \mathrm{~g} \mathrm{C} \mathrm{m}^{-2}\right)$, was 1.6 times greater than that measured in the OUT-patch. The heterotrophic bacterial productivity (BP) increased after day 2 and peaked on 8, then declined afterwards. The delay in the BP increase suggests that the increased DOM supply from phytoplankton accelerated heterotrophic activity. Bacterial C demand (consumption) was fueled through phytoplankton exudation, heterotrophic organisms (meso-zooplankton and protozoa) and cell lysis by viruses. The comprehensive dataset in the Fe-patch survey enabled us to estimate the carbon budget during the development and decline of the bloom. About 33\% of the whole (dissolved + particulate) primary production was exported by sinking particles, and $18 \%$ was transferred to meso-zooplankton net growth. The sum of community respiration was $12.1 \mathrm{~g} \mathrm{C} \mathrm{m}^{-2}$, accounted for $56 \%$ of the whole PP. The export ratio by sinking particles was estimated as 0.49 and 0.67 for the IN-patch and OUT-patch, respectively. The ratio would be higher if including export by the vertical migration of copepods. These high ratios indicate a more efficient biological pump in the western subarctic Pacific Ocean even without supplementary Fe supply than in the eastern subarctic Pacific Ocean. However, more than half (56\%) of the whole PP was respired (returned to $\mathrm{CO}_{2}$ ) within the SML (Fe-patch), and a further fraction of the exported production would be respired at a relatively shallow depth $(\sim 200 \mathrm{~m})$.

\section{Acknowledgements}

We wish to thank the captains and crews of the R.V. Hakuho Maru (Japan) and R.V. Kilo Moana (U.S.A.), and all the scientists and students on board during the cruises for their help and cooperation in the experiment. We also thank Drs. Hiroaki Saito and Akira Kuwata, Tohoku National Fisheries Research Institute, for providing the opportunity to use their mass spectrometer. Funding was provided by the U.S. National Science Foundation (Chemical Oceanography) and U.S. Department of Energy (Ocean Carbon Sequestration Research Program) to WPC. 


\section{References}

Anderson, T.R., Ducklow, H.W., 2001. Microbial loop carbon cycling in ocean environments studied using a simple steady-state model. Aquatic Microbial Ecology 26, 37-49.

Aramaki, T., Nojiri, Y., Imai, K., Behavior of particulate materials during iron fertilization experiments in the western subarctic North Pacific (SEEDS and SEEDS II). Deep-Sea Research II this issue.

Baines, S.B., Pace, M.L., 1991. The production of dissolved organic matter by phytoplankton and its importance to bacteria: Patterns across marine and fresh water systems. Limnology and Oceanography 36, 1078-1090.

Boyd, P.W., Muggli, D.L., Varela, D.E., Goldblatt, R.H., Chretien, R., Orians, K.J., Harrison, P.J., 1996. In vitro iron enrichment experiments in the NE subarctic Pacific. Marine Ecology Progress Series 136, 179-193.

Boyd, P.W., Law, C.S., Wong, C.S., Nojiri, Y., Tsuda, A., Lavasseur, M., Takeda, S., Rivkin, R., Harrison, P.J., Strzepek, R., Gower, J., Mike McKay, R., Abraham, E., Arychuk, M., Barwell-Clarke, J., Crawford, W., Crawford, D., Hale, M., Harada, K., Johnson, K., Kiyosawa, H., Kudo, I., Marchetti, A., Miller, W., Needoba, J., Nishioka, J., Ogawa, H., Page, J., Robert, M., Saito, H., Sastri, A., Sherry, N., Soutar, T., Sutherland, N., Taira, Y., Whitney, F., Wong, S., Yoshimura, T., 2004. The decline and fate of an iron-induced subarctic phytoplankton bloom. Nature 428, 549-553.

Bronk, D.A., Glibert, P.M., Ward, B.B., 1994. Nitrogen uptake, dissolved organic nitrogen release, and new production. Science 265, 183-184.

Caron, D.A., Goldman, J.C., 1990. Protozoan nutrient regeneration. In Capriula, G.M. (Ed.), Ecology of Marine Protozoa. Oxford University Press, New York, pp. 283-306.

Church, M.J., Hutchins, D.A., Ducklow, H.W., 2000. Limitation of bacterial growth by dissolved organic matter and iron in the Southern Ocean. Applied and Environmental Microbiology 66, 455-466. 
Coale, K.H., Johnson, K.S., Fitzwater, S.E., Gordon, R.M., Tanner, S., Chavez, F.P., Ferioli, L., Sakamoto, C., Rogers, P., Millero, F., Steinberg, P., Nightengale, P., Cooper, D., Cochlan, W.P., Landry, M.R., Constantinou, J., Rollwagen, G., Trasvina, A., Kudela, R., 1996. A massive phytoplankton bloom induced by an ecosystem-scale iron fertilization experiment in the equatorial Pacific Ocean. Nature 383, 495-501.

Coale, K.H., Johnson, K.S., Chavez, F.P., Buesseler, K.O., Barber, R.T., Brzezinski, M.A., Cochlan, W.P., Millero, F.J., Falkowski, P.G., Bauer, J.E., Wanninkhof, R.H., Kudela,R.M., Altabet, M.A., Hales, B.E., Takahashi, T., Landry,M.R., Bidigare, R.R., Wang, X.J., Chase, Z., Strutton, P.G., Friederich, G.E., Gorbunov, M.Y., Lance, V.P., Hilting,A.K., Hiscock, M.R., Demarest, M., Hiscock, W.T., Sullivan, K.F., Tanner, S.J., Gordon, R.M., Hunter, C.N., Elrod, V.A.,Fitzwater, S.E., Jones, J.L., Tozzi, S., Koblizek, M., Roberts, A.E., Herndon, J., Brewster, J., Ladizinsky, N., Smith, G., Cooper, D., Timothy, D., Brown, S.L., Selph, K.E., Sheridan,C.C., Twining, B.S., Johnson, Z.I., 2004. Southern ocean iron enrichment experiment: carbon cycling in high- and low-Si waters. Science 304, 408-414.

Cochlan, W.P., Kudela, R.M, 1996. Inorganic and organic nitrogen uptake dynamics in the equatorial Pacific during Iron Ex II. Eos 76, OS177 (Abstract).

Cochlan, W.P., 2001. The heterotrophic bacterial response during a mesoscale iron enrichment experiment (Iron Ex II) in the eastern equatorial Pacific Ocean. Limnology and Oceanography 46, 428-435.

Cochlan, W.P., Bronk, D.A., 2001. Nitrogen uptake kinetics in the Ross Sea, Antarctica. Deep-Sea Research II 48, 4127-4153.

Cochlan, W.P., Bronk, D.A., Coale, K.H., 2002. Trace metals and nitrogenous nutrition of Antarctic phytoplankton: experimental observations in the Ross Sea. Deep-Sea Research II 49, 3368-3390.

Cochlan, W.P., Kudela. R.M., 2006. The Southern Ocean iron enrichment experiment: the nitrogen uptake response, p. 27-31. In: S. Takeda and C.S. Wong [Eds.], Report of the 2004 Workshop on In Situ Iron Enrichment Experiments in the Eastern and Western Subarctic Pacific. PICES Scientific Report 31, 187 pp. 
Copping, A.E., Lorenzen, C.J., 1980. Carbon budget of a marine phytoplankton-herbivore system with carbon-14 as a tracer. Limnology and Oceanography 25, 873-882.

de Baar, H.J.W, Boyd, P.W., Coale, K.H., Landry, M.R., Tsuda, A., Assmy, P., Bakker, D.C.E., Bozec, Y., Barber, R.T., Brzezinski, M.A., Buesseler, K.O., Boye, M., Croot, P.L., Gervais, F., gorbunov, M.Y., Harrison, P.J., Hiscock, W.T., Laan, P., Lancelot, C., Law, C.S., Levasseur, M., Marchetti, A., Millero, F.J., Nishioka, J., Nojiri, Y., van Oijen, T., Riebesell, U., Rijkenberg, M.J.A., Saito, H., Takeda, S., Timmermans, K.R., Veldhuis, M.J.W., Waite, A.M., Wong, C.S., 2005. Syntesis of iron fertilization experiments: From the iron age in the age of enlightenment. Journal of Geophysical Research, 110, doi:10.1029/2004JC002601.

del Giorgio, P.A., Cole, J.J. (2000). Bacterial Energetics and Growth Efficiency. Microbial ecology of the oceans. Kirchman, D.L. (Ed.) New York, A John Wiley \& Sons: 289-326.

Dugdale, R.C., Goering, J.J., 1967. Uptake of new and regenerated frms of nitrogen in primary productivity. Limnology and Oceanography 12, 196-206.

Dugdale, R.C., Wilkerson, F.P., 1986. The use of ${ }^{15} \mathrm{~N}$ to measure nitrogen uptake in eutrophic oceans; experimental considerations. Limnology and Oceanography 31, 673-689.

Eppley, R.W., Peterson, B.J., 1979. Particulate organic matter flux and planktonic new production in the deep ocean. Nature 282, 677-680.

Falkowski, P.G., Raven, J.A., 1997. Aquatic Photosynthesis, Blackwell Science, Inc., Massachusetts.

Glibert, P.M., Lipschultz, F., McCarthy, J.J., Altabet, M.A., 1982. Isotope dilution models of uptake and remineralization of ammonium by marine plankton. Limnology and Oceanography 27, 639-650.

Hale, M.S., Rivkin, R.B., Matthews, P., Agawin, N.S.R., Li, W.K.W., 2006. Mirobial response to a mesoscale iron enrichment in the NE subarctic Pacific: Heterotropic bacterial processes. Deep-Sea Research II 53, 2231-2247. 
Hall, J.A., Safi, K., 2001. The impact of in situ Fe ferilisation on the microbial food web in the Southern Ocean. Deep-Sea Research II 48, 2591-2613.

Hama, T., Miyazaki, T., Ogawa, Y., Iwakuma, T., Takahashi, M., Otsuki, A., Ichimura, S., 1983. Measurement of photosynthetic production of a marine phytoplankton population using a stable ${ }^{13} \mathrm{C}$ isotope. Marine Biology 73, 31-36.

Imai, K., Nojiri, Y., Tsurushima, N., Saino, T., 2002. Time series of seasonal variation of primary productivity at station KNOT $\left(44^{\circ} \mathrm{N}, 155^{\circ} \mathrm{E}\right)$ in the sub-arctic western North Pacific. Deep-Sea Research II 49, 5395-5408.

Kawakami, H., Honda, M. C. 2007. Time-series observation of POC fluxes estimated from ${ }^{234}$ Th in the northwestern North Pacific. Deep-Sea Research I 54, 1070-1090.

Kirchman, D.L., K’Ness, E., Hodson, R., 1985. Leucine incorporation and its potential as a measure of protein synthesis by bacteria in natural aquatic systems. Applied and Environmental Microbiology 49, 599-607.

Kirchman, D.L., Keil, R.G., Simon, M., Welschmeyer, N.A., 1993. Biomass and production of heterotrophic bacterioplankton in the oceanic subarctic Pacific. Deep-Sea Research II 40, 967-988.

Kirchman, D.L., Rich, J.H., 1997. Regulation of bacterial growth rates by dissolved organic carbon and temperature in the equatorial Pacific Ocean. Microbial Ecology 33, 11-20.

Kirchman, D.L., Meon, B., Cottrell, M.T., Hutchins, D.A., Weeks, D., Bruland, K.W., 2000. Carbon versus iron limitation of bacterial growth in the California upwelling regime. Limnology and Oceanography 45, 1681-1688.

Kudo, I., Miyamoto, M., Noiri, Y., Maita, Y., 2000. Combined effects of temperature and iron on the growth and physiology of the marine diatom Phaeodactylum tricornutum (Bacillariophyceae). Journal of Phycology 36, 1096-1102. 
Kudo, I., Noiri, Y., Imai, K., Nojiri, Y., Nishioka, J., Tsuda, A., 2005. Primary productivity and nitrogenous nutrient assimilation dynamics during the Subarctic Pacific Iron Experiment for Ecosystem Dynamics Study. Progress in Oceanography 64, 207-222.

Kudo, I., Noiri, Y., Nishioka, J., Taira, Y., Kiyosawa, H., Tsuda, A., 2006. Phytoplankton community response to Fe and temperature gradients in the NE (SERIES) and NW (SEEDS) subarctic Pacific Ocean. Deep-Sea Research II 53, 2201-2213.

Maldonado, M.T., Price, N.M., 1999. Utilization of iron bound to strong organic ligands by plankton communities in the subarctic Pacific Ocean. Deep-Sea Research II 46, 2447-2473.

Marchetti, A, Juneau, P., Whitney, F.A., Wong, C.-S., Harrison, P.J., 2006a. Phytoplankton processes during a mesoscale iron enrichment in the NE subarctic Pacific: Part I-Nutrient utilization. Deep-Sea Research II 53, 2114-2130.

Marchetti, A., Sherry, N.D., Juneau, P., Strzepek, R.F., Harrison, P.J., 2006b. Phytoplankton processes during a mesoscale iron enrichment in the NE subarctic Pacific: Part II-Primary productivity. Deep-Sea Research II 53, 2131-2151.

Marie, D., Partensky, F., Jacquest, S., Vaulot, D., 1997. Enumeration and cell cycle analysis of natural population of marine picoplankton by flow cytometry using the nucleic acid stain SYBR Green I. Applied and Environmental Microbiology 63, 186-193.

Martin, J.H., Coale, K.H., Johnson, K.S., Fitzwater, S.E., Gordon, R.M., Tanner, S.J., Hunter, C.N., Elrod, V.A., Nowicki, J.L., Coley, T.L., Barber, R.T., Lindley, S., Watson, A.J., Van Scoy, K., Law, C.S., Liddicoat, M.I., Ling, R., Stanton, T., Stockel, J., Collins, C., Anderson, A., Bidigare, R., Ondrusek, M., Latasa, M., Millero, F.J., Lee, J., Yao, W., Zhang, J.Z., Friederich, G, Sakamoto C, Chavez, F., Buck, K., Kolber, Z., Greene, R., Falkowski, P., Chisholm, S.W., Hoge, F, Swift R, Yungel, J., Turner, S., Nightingale, P., Hatton, A., Liss, P., Tindale, N.W., 1994. Testing the iron hypothesis in ecosystems of the equatorial Pacific Ocean. Nature 371, 123-129.

Meon, B., Kirchman, D.L., 2001. Dynamics and molecular composition of dissolved organic material during experimental phytoplankton blooms. Marine Chemistry 75, 185-199. 
Milligan, A.J., Harrison, P.J., 2000. Effects of non-steady state iron limitation on nitrogen assimilatory enzymes in the marine diatom Thalassiosira weissflogii (Bacillariophyceae). Journal of Phycology 36, 78-86.

Montagnes, D.J., Berges, J.A., Harrison, P.J., Taylor, F.J.R., 1994. Estimating carbon, nitrogen, protein, and chlorophyll $a$ from volume in marine phytoplankton. Limnology and Oceanography 39, 1044-1060.

Nagata, T., 2000. Production mechanisms of dissolved organic matter. In Microbial ecology of the oceans. Kirchman, D. L.(Ed.), A John Wiley \& Sons, New York, 121-152.

Noiri, Y., Kudo, I., Kiyosawa, H., Nishioka, J., Tsuda, A., 2005. Influence of iron and temperature on growth, nutrient utilization ratios and phytoplankton species composition in the western subarctic Pacific Ocean during the SEEDS experiment. Progress in Oceanography 64, $149-166$

Norrman, B., Zweifel U.L., Hopkinson, Jr. C.S., Fry, B. 1995. Production and utilization of dissolved organic carbon during an experimental diatom bloom. Limnology and Oceanography 40, 898-907.

Price, N.M., Andersen, L.F., Morel, F.M.M., 1991. Iron and nitrogen nutrition of equatorial Pacific plankton. Deep-Sea Research, 38 1361-1378.

Price, N.M., Ahner, B.A., Morel, F.F., 1994. The equatorial Pacific Ocean: Grazer-controlled phytoplankton populations in an iron-limited ecosystem. Limnology and Oceanography, 39, 520-534.

Rivkin, R.B., Legendre, L., 2001. Biogenic carbon cycling in the upper ocean: effects of microbial respiration. Science 291, 2398-2400.

Saito, H., Tsuda, A., Nojiri, Y., Aramaki, T., Ogawa, H., Yoshimura, T., Imai, K., Kudo, I., Nishioka, J., Ono, T., Suzuki, K., Takeda, T. Biogeochemical cycling of N and Si during the mesoscale iron-enrichment experiment in the western subarctic Pacific (SEEDS-II). Deep-Sea Research II, this issue. 
Sherry, N.D., Boyd, P.W., Sugimoto, K., Harrison, P.J., 1999. Seasonal and spatial patterns of heterotrophic bacterial production, respiration, and biomass in the subarctic NE Pacific. Deep-Sea Research II 49, 5775-5791.

Simon, M., Azam, F., 1989. Protein content and synthesis rates of planktonic marine bacteria. Marine Ecology Progress Series 51, 201-213.

Strom, S.L., Benner, R., Ziegler, S., Dagg, M.J., 1997. Planktonic grazers are a potentially important source of marine dissolved organic carbon. Limnology and Oceanography 42, 1364-1374.

Suzuki, R., Ishimaru, T., 1990. An improved method for the determination of phytoplankton chlorophyll using N, N-dimethylformamide. Journal of Oceanographic Society of Japan 46,190-194.

Suzuki, K., Hinuma, A., Saito, H., Kiyosawa, H., Liu, H., Saino, T., Tsuda, A., 2005. Responses of phytoplankton and heterotrophic bacteria in the northwest subarctic Pacific to in situ iron fertilization as estimated by HPLC pigment analysis and flow cytometry. Progress in Oceanography 64, 167-187.

Timmermans, K.R., Stolte, W., de Baar, H.J.W., 1994. Iron-mediated effects on nitrate reductase in marine phytoplankton. Marine Biology 121, 389-396.

Timmermans, K.R., van Leeuwe, M.A., de Jong, J.T.M., McKay, R.M.L., Nolting, R.F., Witte, H.J., van Ooyen, J., Swagerman, M.J.W., Kloosterhuis, H., de Baar, H.J.W., 1998. Iron stress in the Pacific region of the Southern Ocean: evidence from enrichment bioassays. Marine Ecology Progress Series 166, 27-41.

Tsuda, A., Takeda, S., Saito, H., Nishioka, J., Nojiri, Y., Kudo, I., Kiyosawa, H., Shiomoto, A., Imai, K., Ono, T., Shimamoto, A., Tsumune, D., Yoshimura, T., Aono, T., Hinuma, A., Kinugasa, M., Suzuki, K., Sohrin, Y., Noiri, Y., Tani, H., Deguchi, Y., Tsurushima, N., Ogawa, H., Fukami, K., Kuma, K., Saino, T., 2003. A mesoscale iron enrichment in the western subarctic Pacific induces a large centric diatom bloom. Science 300, 958-961. 
Tsuda, A., Saito, H., Nishioka, J., Ono, T., 2005. Mesozooplankton responses to iron-fertilization in the western subarctic Pacific (SEEDS 2001). Progress in Oceanography 64, 237-251.

Tsuda, A., Takeda, S., Saito, H., Nishioka, J., Kudo, I., Nojiri, Y., Suzuki, K., Uematsu, M., Wells, M. L., Tsumune, D., Yoshimura, T., Aono, T., Aramaki, T., Cochlan, W.P., Hayakawa, M., Imai, K., Isada, T., Iwamoto, Y., Johnson, W.K., Kameyama, S., Kato, S., Kiyosawa, H., Kondo, K., Levasseur, M., Machida, R., Nagao, I., Nakagawa, F., Nakanishi, T., Nakatsuka, S., Narita, A., Noiri, Y., Obata, H., Ogawa, H., Oguma, K., Ono, T., Sakuragi, T., Sasakawa, M., Sato, M., Shimamoto, A., Takata, H., Trick, C.G., Watanabe, Y.Y., Wong, C.S., Yoshie, N., 2007. Evidence for the grazing hypothesis: Grazing reduces phytoplankton responses of the HNLC ecosystem to iron enrichment in the western subarctic Pacific (SEEDS II). Journal of Oceanography 63, 983-994.

Tsuda, A., Saito, H., Machida, R., Shimode, S. Meso and microzooplankton responses in the northwest subarctic Pacific during in situ iron fertilization experiment (SEEDS-II). Deep-Sea Research II this issue.

Tsumune, D., Nishioka, J., Shimamoto, A., Takeda, S., Tsuda, A., 2005. Physical behavior of the SEEDS iron-fertilized patch by surphur hexafluoride tracer release. Progress in Oceanography 64, 111-127.

Yoshimura, T., Ogawa, H., Imai, K., Aramaki, T., Nojiri, Y., Nishioka, J., Tsuda, A. Dynamics of organic carbon, nitrogen and phosphorus in particulate and dissolved organic pools during a phytoplankton bloom induced by in situ iron experiment in the western subarctic Pacific (SEEDS-II). Deep-Sea Research II this issue.

Welschmeyer, N.A., 1994. Fluorometric analysis of chlorophyll $a$ in the presence of chlorophyll $b$ and pheopigments. Limnology and Oceanography 39, 1985-1992.

White, J.R., Roman, M.R., 1992. Seasonal study of grazing by metazoan zooplankton in the mesohaline Chesapeake Bay. Marine Ecology Progress Series 86, 251-261. 


\section{Figure legend}

Figure 1 Contour plots of the temporal change in vertical distributions within the IN-patch for salinity (A), temperature (B), nitrate (C), ammonium (D), Chl-a (E), primary productivity (F), bacterial abundance $(\mathrm{G})$ and bacterial productivity $(\mathrm{H})$. The first Fe enrichment was conducted on day 0 . Dotted line indicates the bottom of the surface mixed layer.

Figure 2 Temporal changes in the concentration of nitrate (A) and silicic acid (B) and phosphate (C) at $5 \mathrm{~m}$ in the IN-patch and OUT-patch.

Figure 3 Temporal changes in nitrate (A) and ammonium (B) inventories in the upper $0-20 \mathrm{~m}$ of the IN-patch and OUT-patch.

Figure 4 Temporal change in the concentration of size-fractionated Chl- $a(\mathrm{~A})$, and the relative proportion of each size fraction to the total Chl- $a$ (B) at $5 \mathrm{~m}$ in the IN-patch.

Figure 5 Temporal change in SML-integrated particulate primary productivity of the IN-patch and OUT-patch. Integration for both patches was conducted from the surface to the corresponding depth of the IN-patch SML. (see text for details).

Figure 6 Temporal changes in particulate $\mathrm{N}$-specific uptake rates of nitrate and ammonium (A) and absolute uptake rates of nitrate and ammonium (B) at the depth of $55 \% \mathrm{I}_{0}$.

Figure 7 The $f$-ratio as a function of time at the depth of $55 \% \mathrm{I}_{0}$ for the IN-patch and OUT-patch.

Figure 8 Temporal changes in SML integrated bacterial biomass (A) and SML integrated bacterial productivity (B) in the IN-patch and OUT-patch. Integration for both patches was conducted until the SML depth of the IN-patch.

Figure 9 Assimilation number as a function of time at the depth of $55 \% \mathrm{I}_{0}$ for the IN-patch and OUT-patch.

Figure 10 Bacterial carbon demand (BCD) as a function of time for the IN-patch and OUT-patch.

Figure 11 Carbon flow in the IN-patch (SML) between days 0 and 23. LP and SP denote large and small phytoplankton, and $\mathrm{B}, \mathrm{V}, \mathrm{P}$ and $\mathrm{Z}$ denote heterotrophic bacteria, viruses, protozoa and meso-zooplankton (copepods), respectively. VM denotes ontogenetic vertical migration of meso-zooplankton which is expressed as dashed line because this flux was not considered in this calculation. All values are in units of $\mathrm{g} \mathrm{C} \mathrm{m}^{-2}$. $*$ The net POC decrease of $1.5 \mathrm{~g} \mathrm{C} \mathrm{m}^{-2}$ was removed as settling particles. 
Table 1 Light depths (m) for sampling for primary productivity measurements during SEEDS II.

\begin{tabular}{|c|c|c|c|c|c|c|c|c|c|c|c|}
\hline & \multicolumn{8}{|c|}{ In Patch } & \multicolumn{3}{|c|}{ Out Patch } \\
\hline & day 0 & day 2 & day 5 & day 8 & day 11 & day 17 & day 23 & day 25 & day 11 & day 15 & day 24 \\
\hline $100 \%$ & 2 & 2 & 2 & 2 & 2 & & 2 & 2 & 2 & & 2 \\
\hline $55 \%$ & 7 & 5 & 3 & 2 & 4 & 3 & 4 & 6 & 4 & 4.5 & 6 \\
\hline $33 \%$ & 11.5 & 8.5 & 6 & 5 & 7 & 7 & 10.5 & 11.5 & 7 & & 11.5 \\
\hline $10 \%$ & 20.5 & 19 & 14 & 11 & 14 & 12 & 14 & 22 & 18 & 21 & 22 \\
\hline $3 \%$ & 30 & 29 & 24 & 18.5 & 23 & 18 & 23 & 33 & 26 & 33 & 33 \\
\hline $1 \%$ & 41 & 41 & 33 & 25 & 34 & 28 & 34 & 46 & 38 & 46 & 4 \\
\hline
\end{tabular}




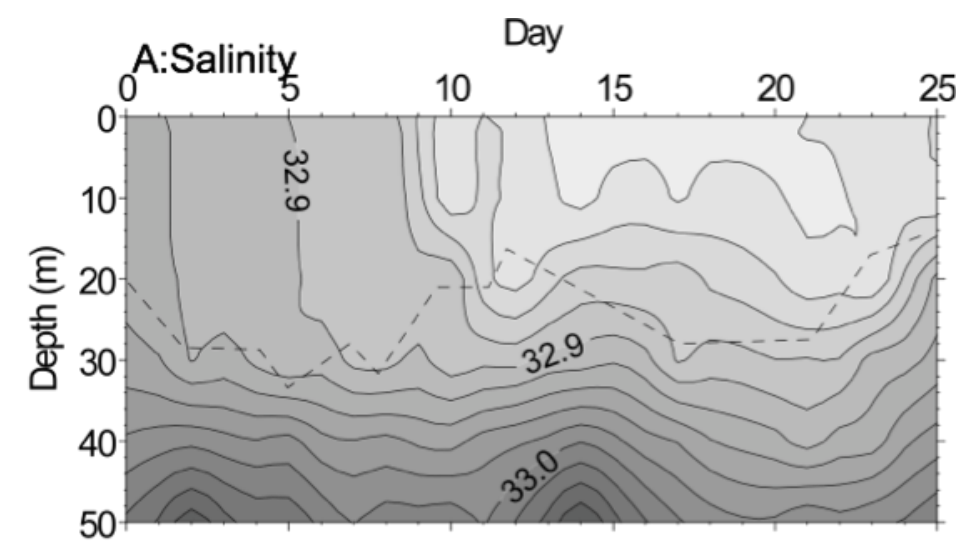

B: Temp $\left({ }^{\circ} \mathrm{C}\right)$
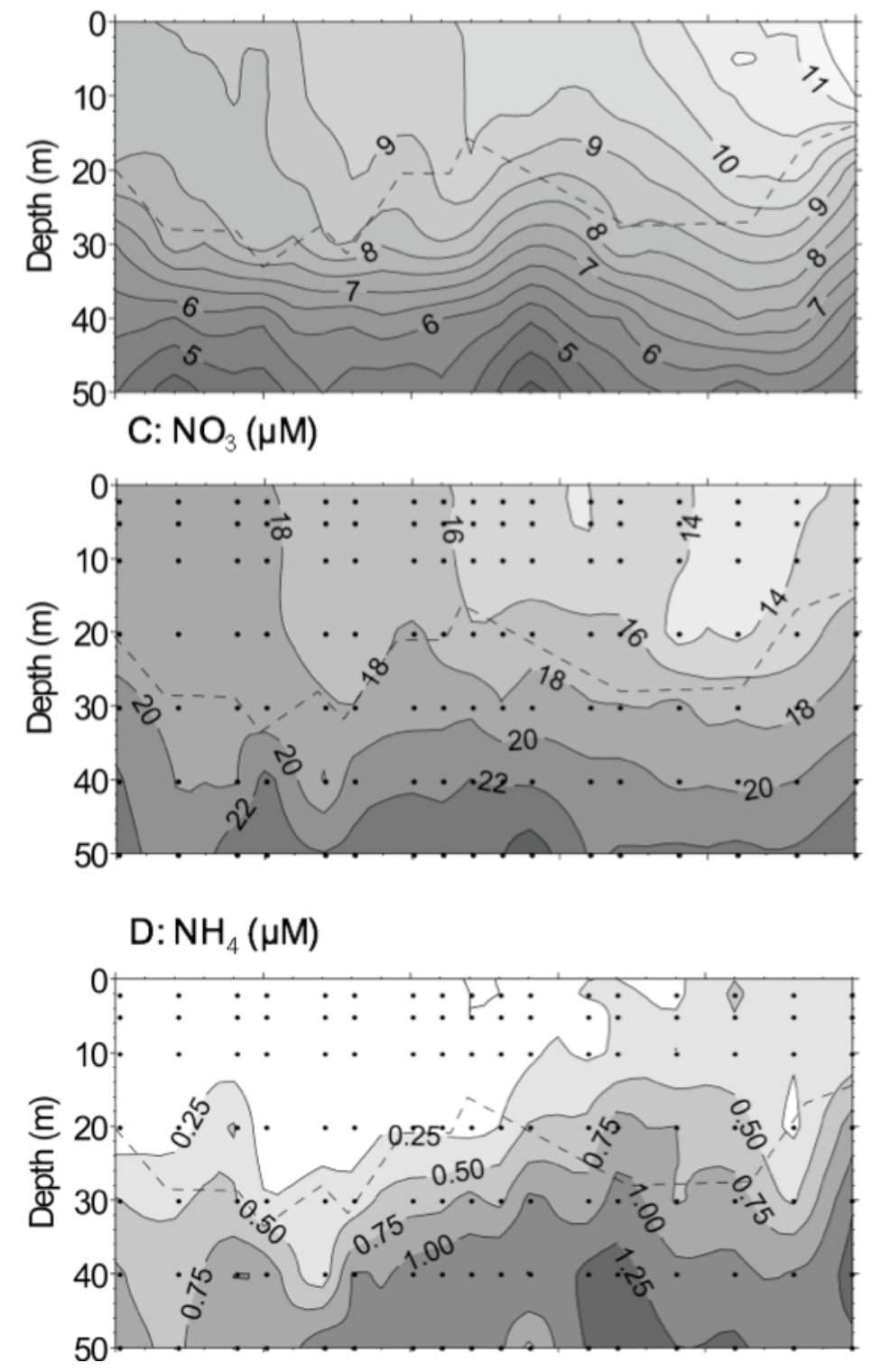

Fig. 1 Kudo et al. 


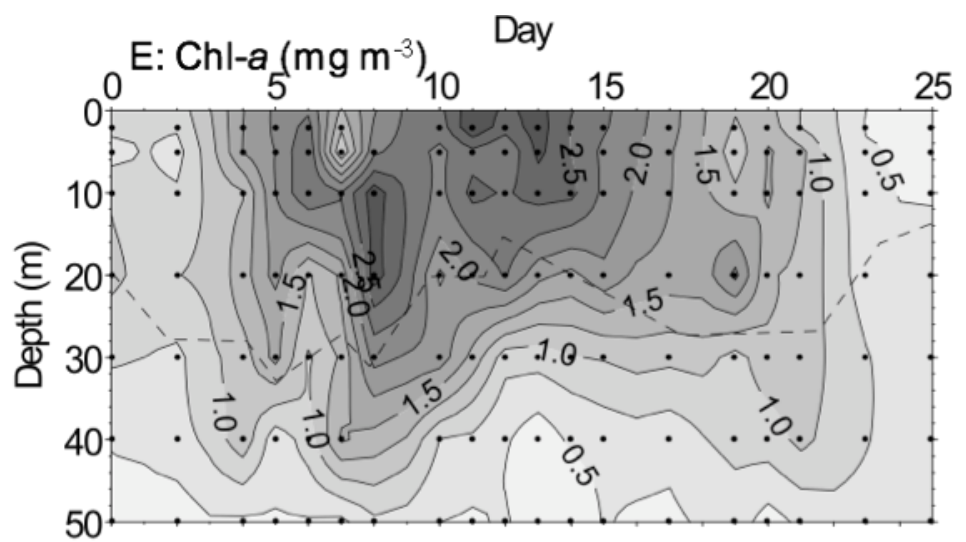

\section{F:PP $\left(\mathrm{mg} \mathrm{C} \mathrm{m}^{-3} \mathrm{~d}^{-1}\right)$}
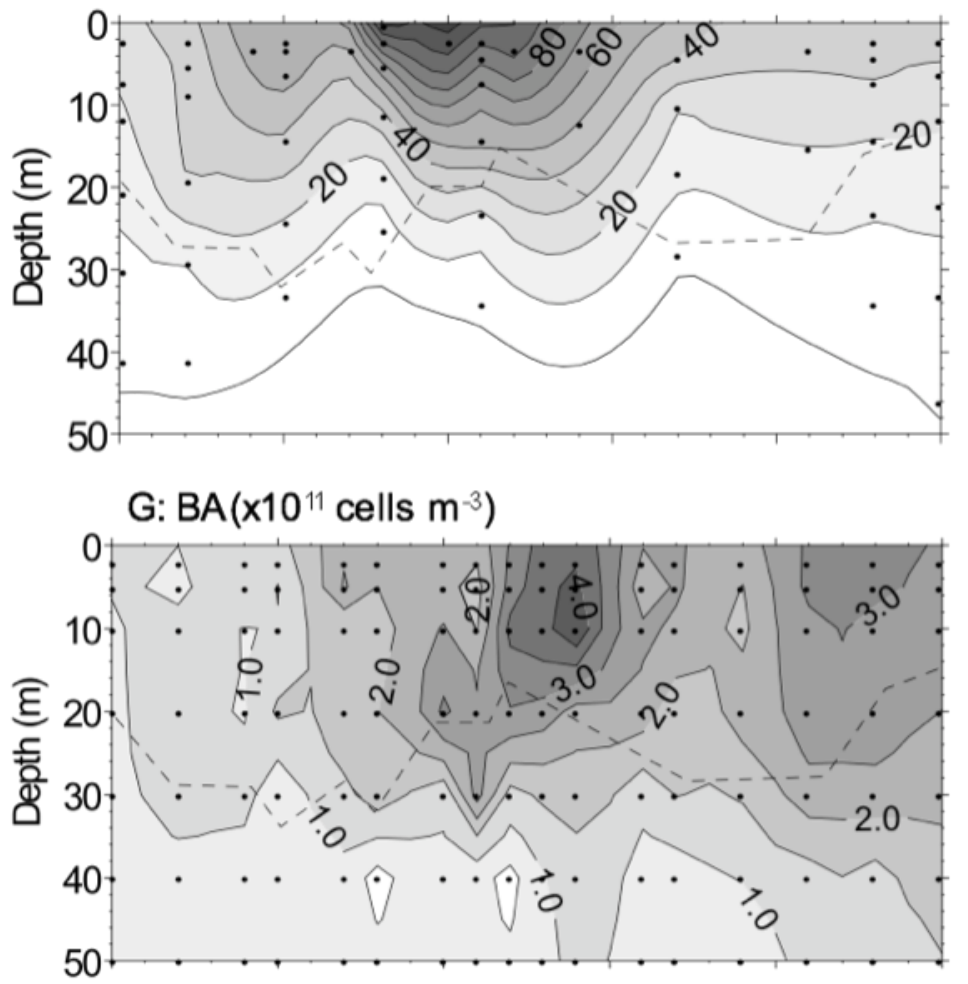

\section{$\mathrm{H}: \mathrm{BP}\left(\mathrm{mg} \mathrm{C} \mathrm{m}^{-3} \mathrm{~d}^{-1}\right)$}

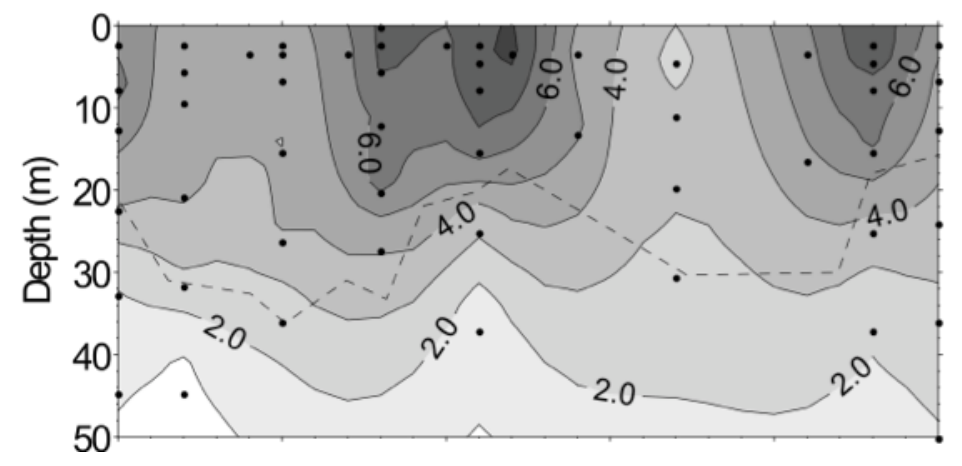

Fig. 1 Kudo et al. 

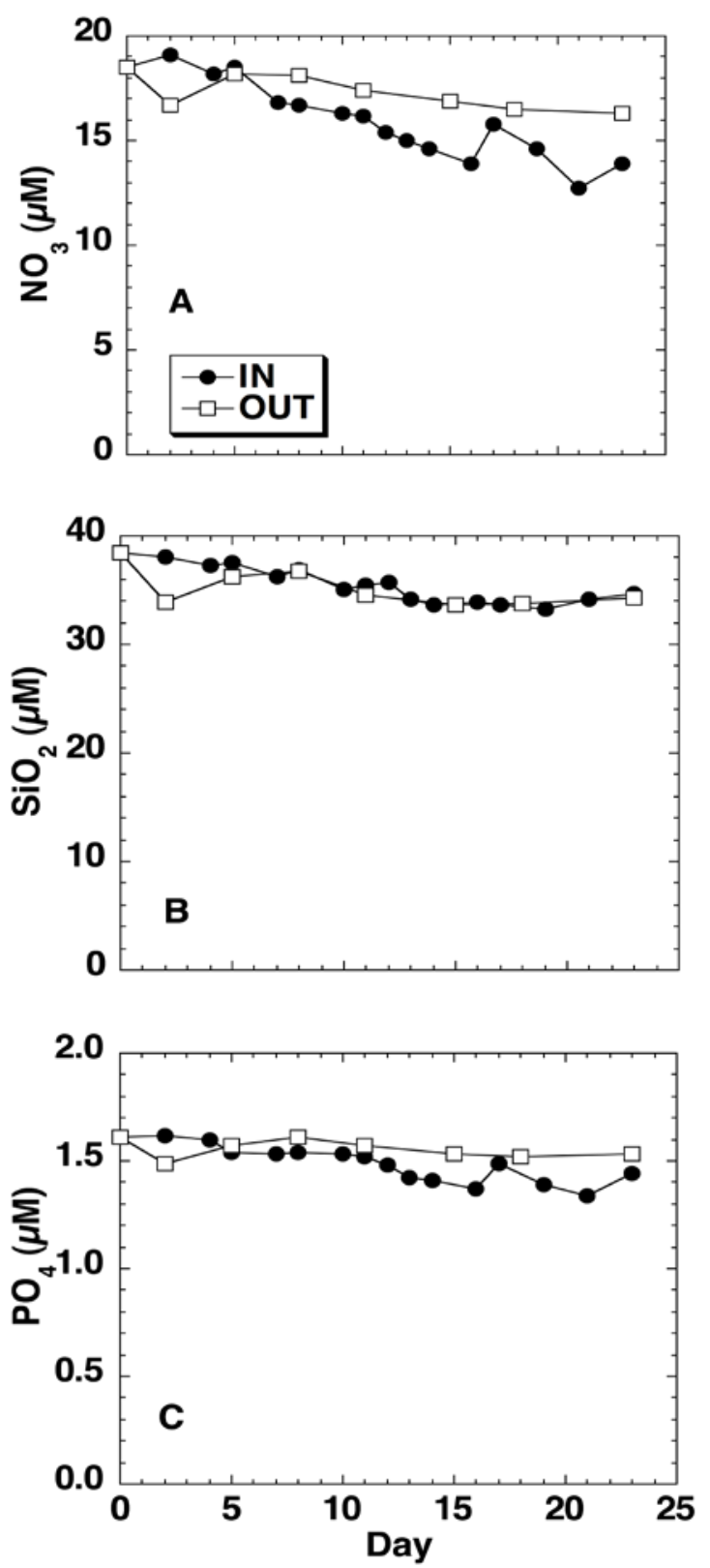

Fig. 2 Kudo et al. 

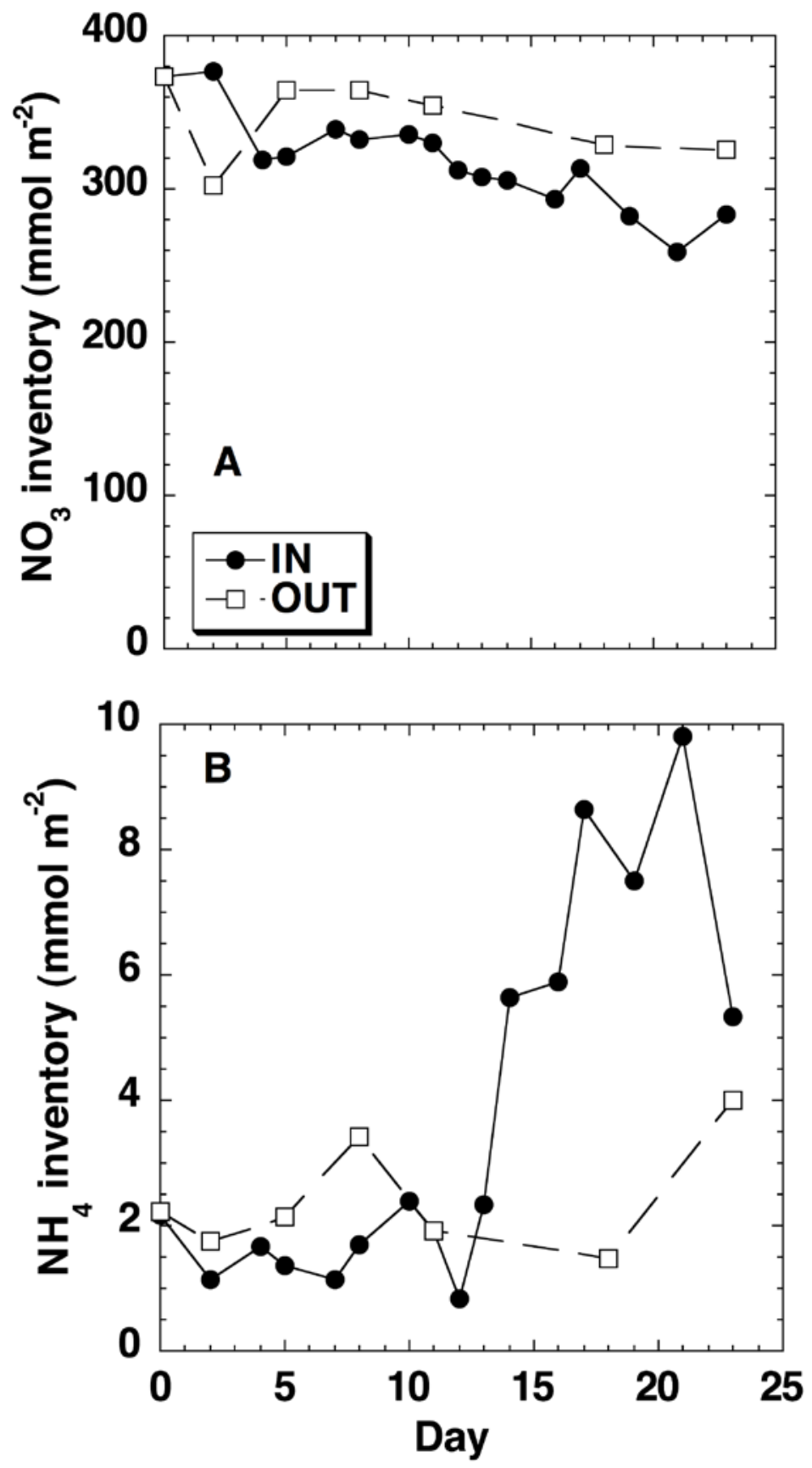

Fig. 3 Kudo et al. 


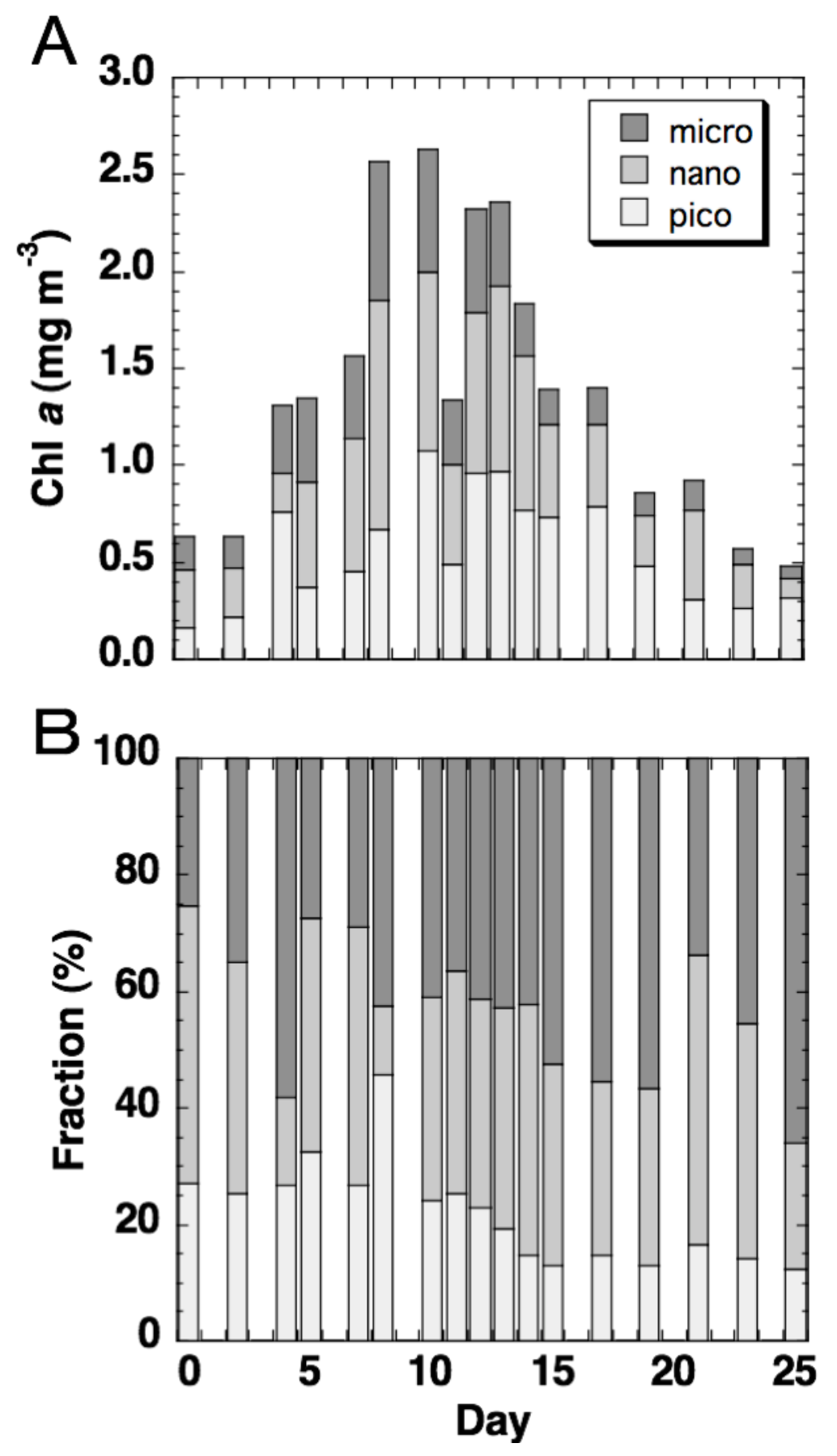

Fig. 4 Kudo et al. 


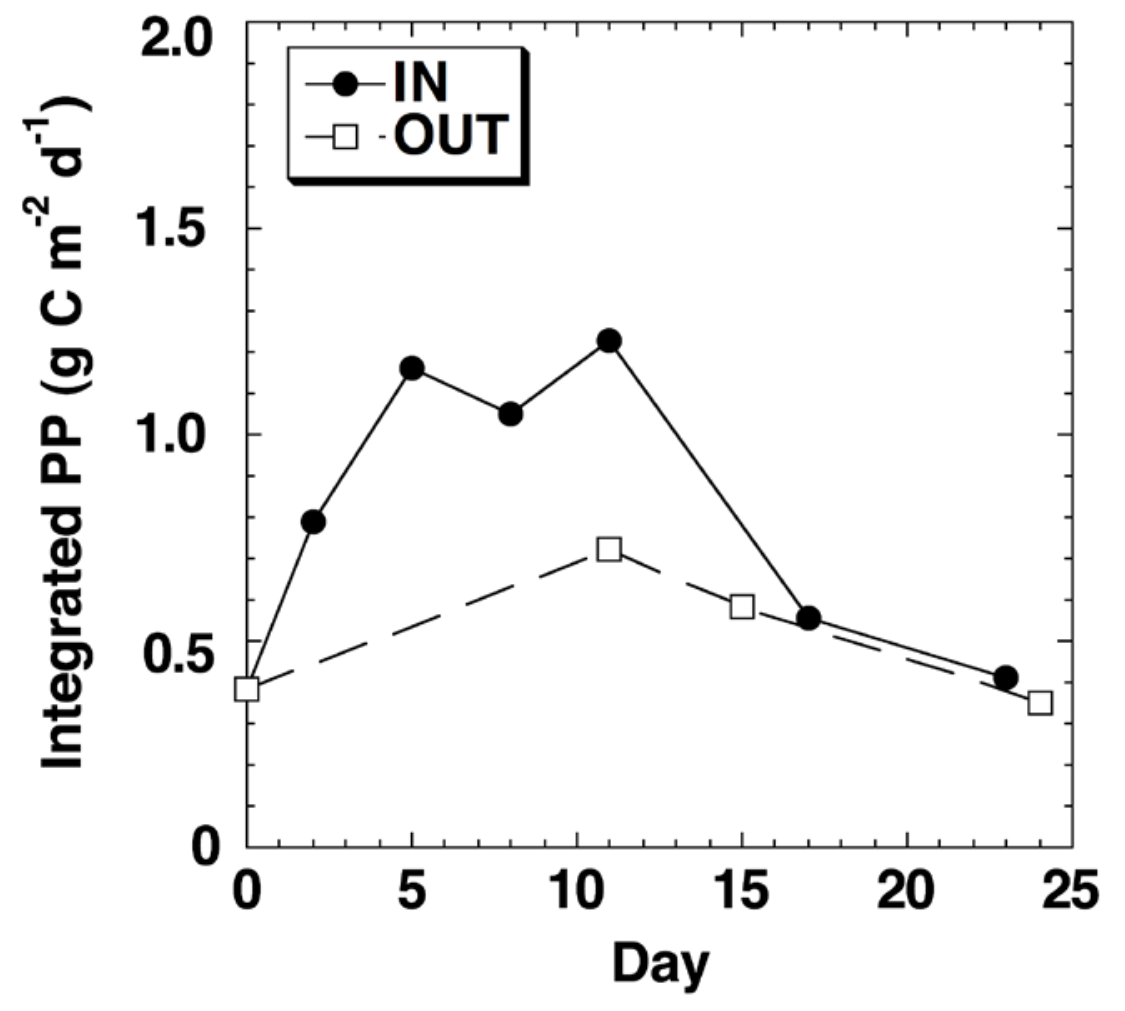

Fig. 5 Kudo et al. 

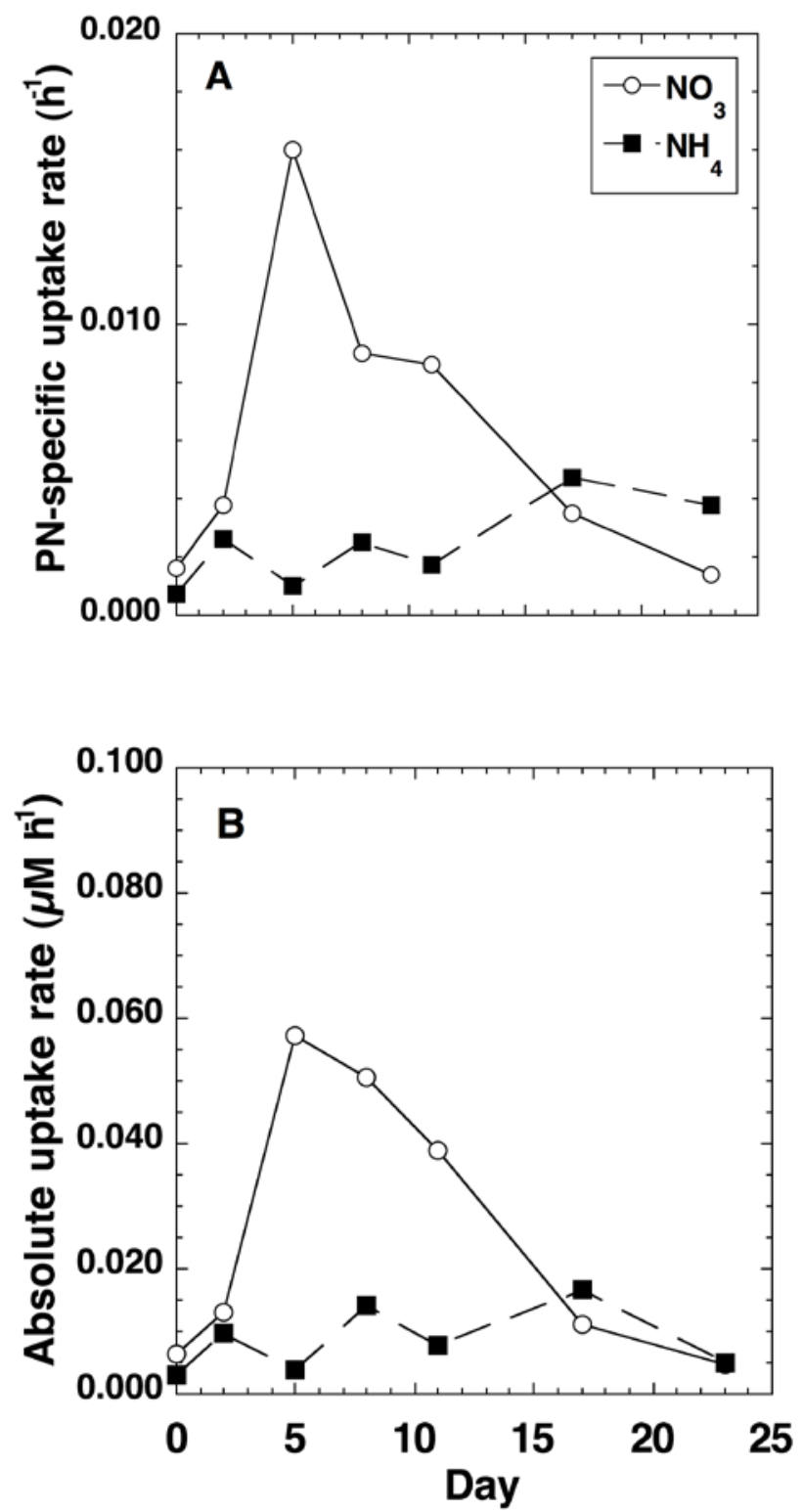

Fig. 6 Kudo et al. 


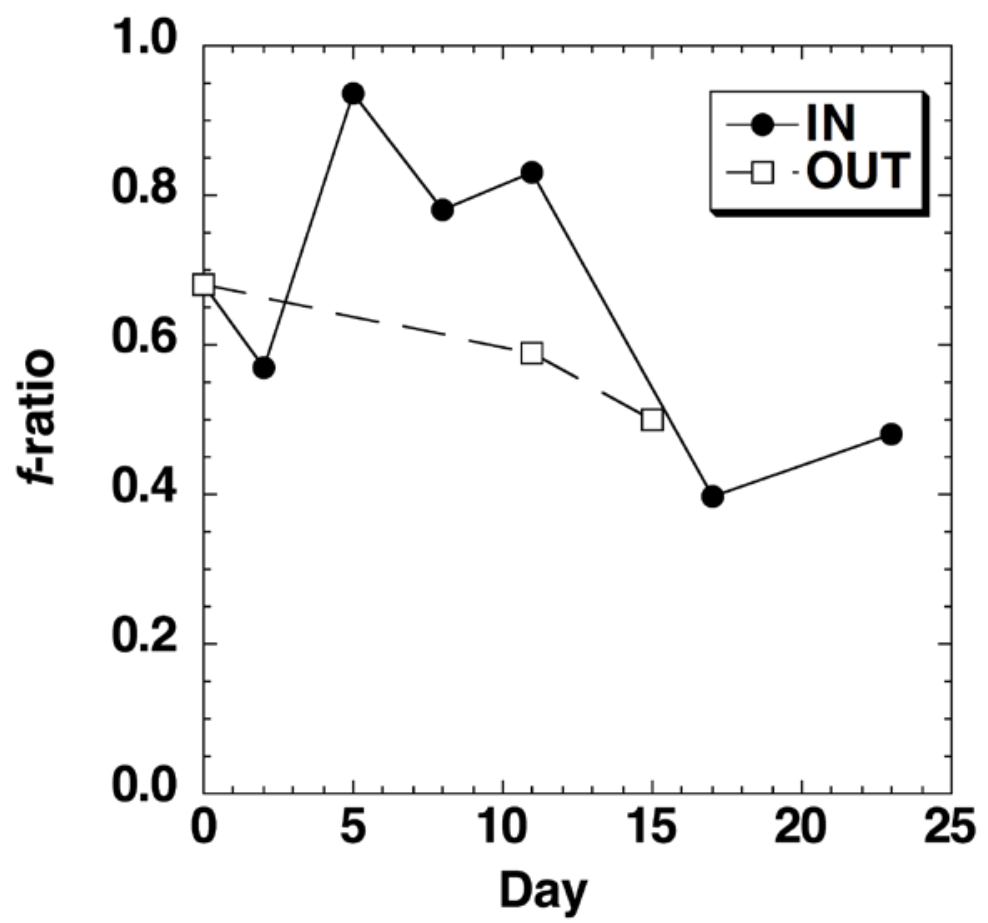

Fig. 7 Kudo et al. 

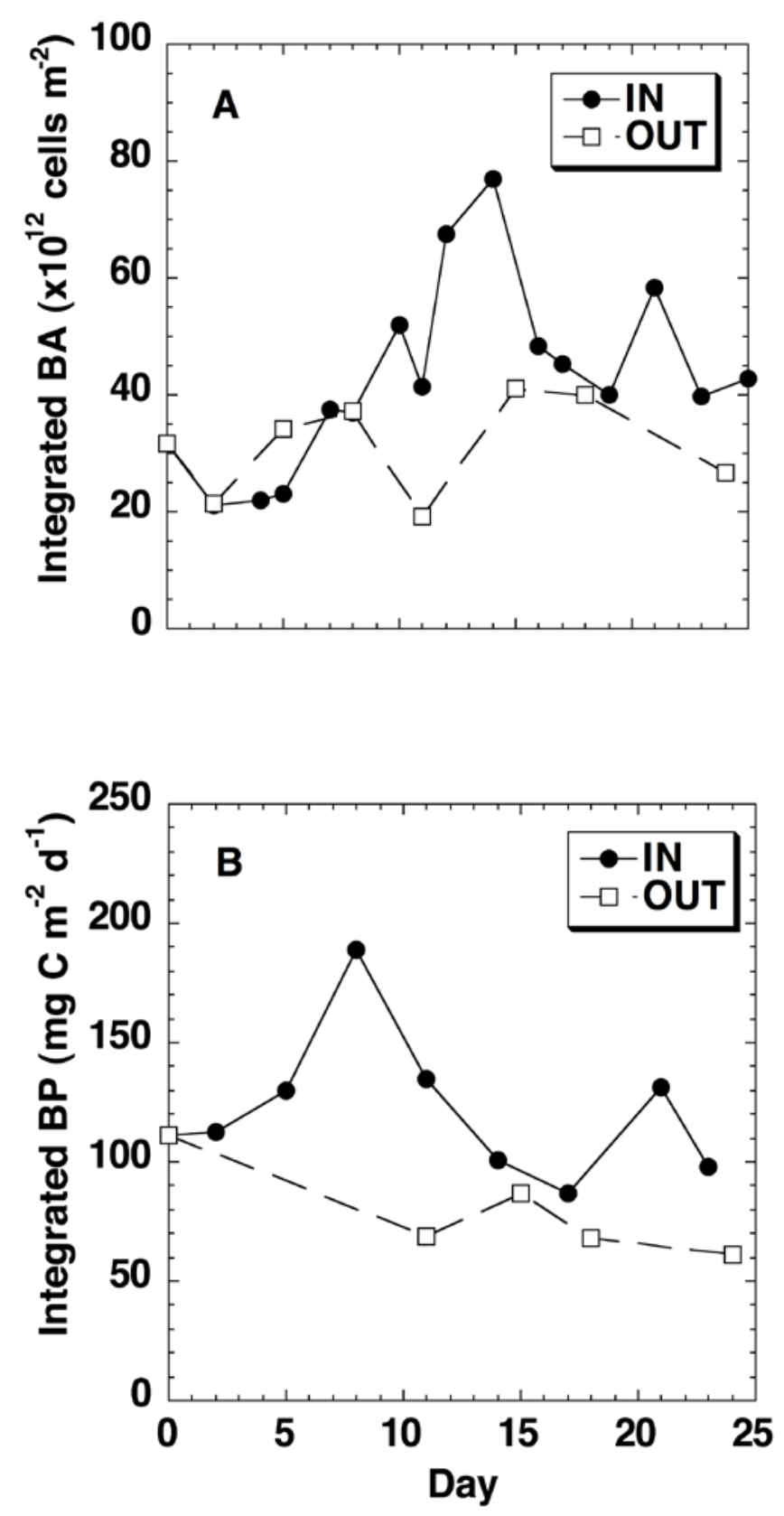

Fig. 8 Kudo et al. 


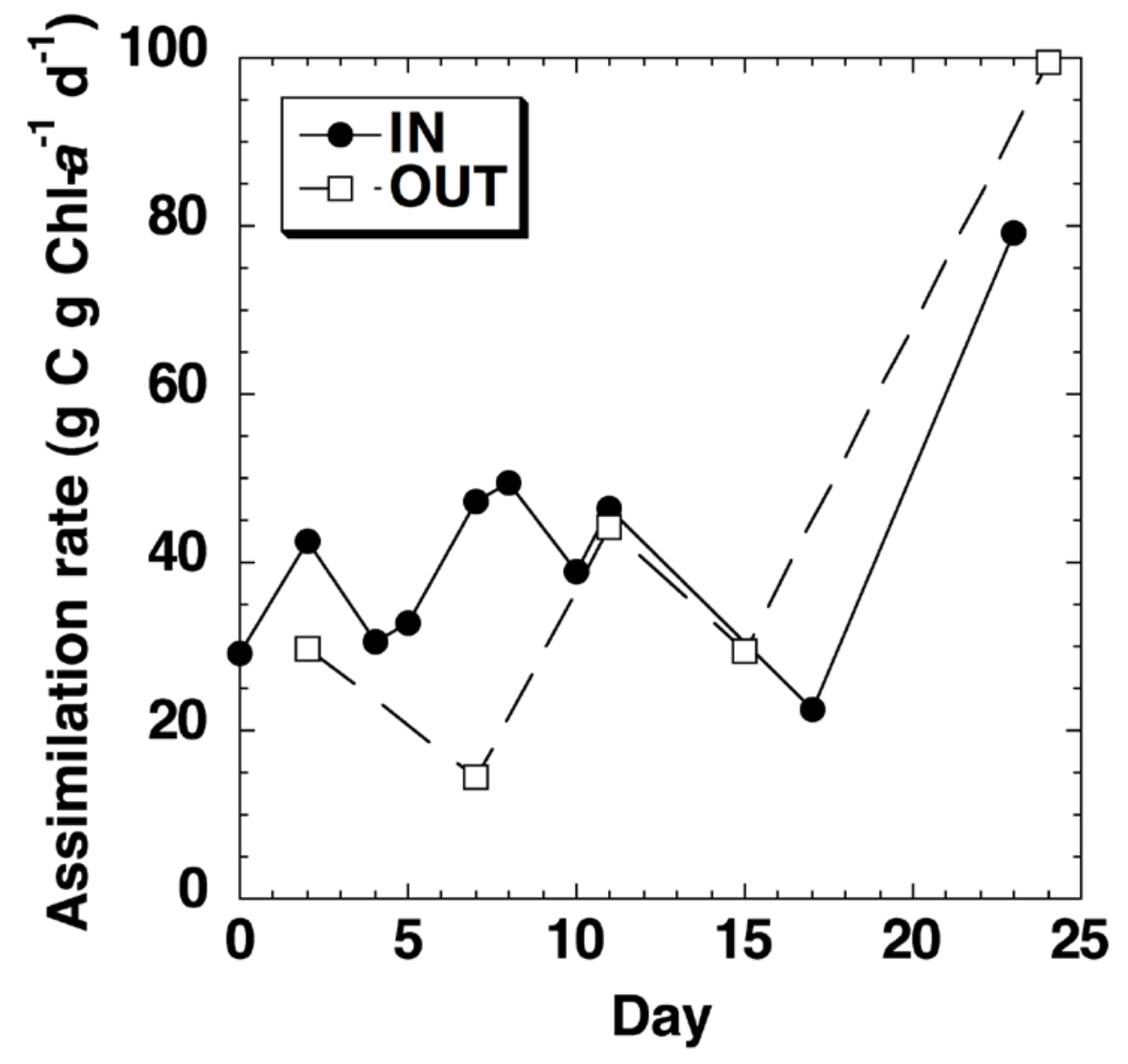

Fig. 9 Kudo et al. 


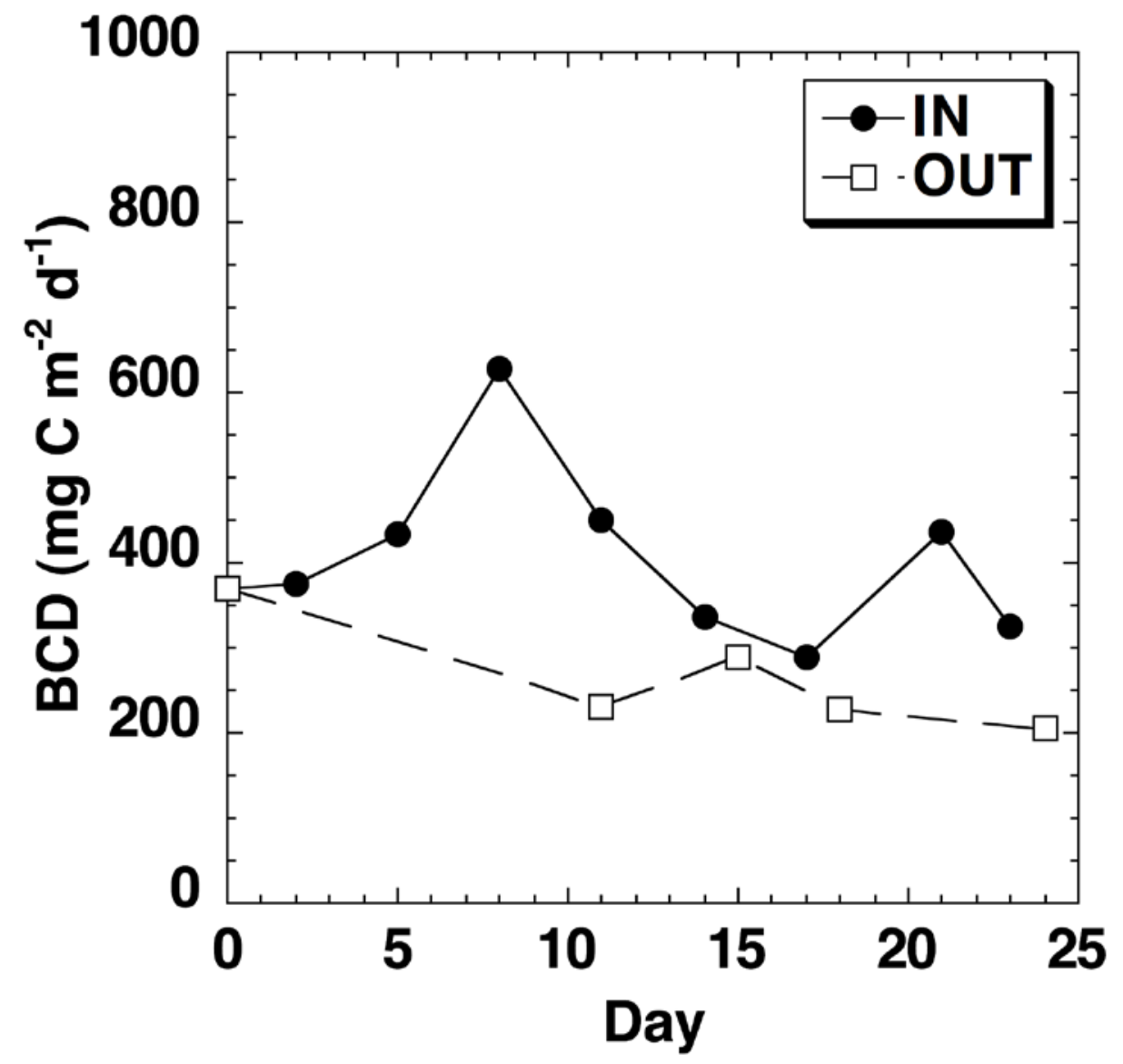

Fig. 10 Kudo et al. 


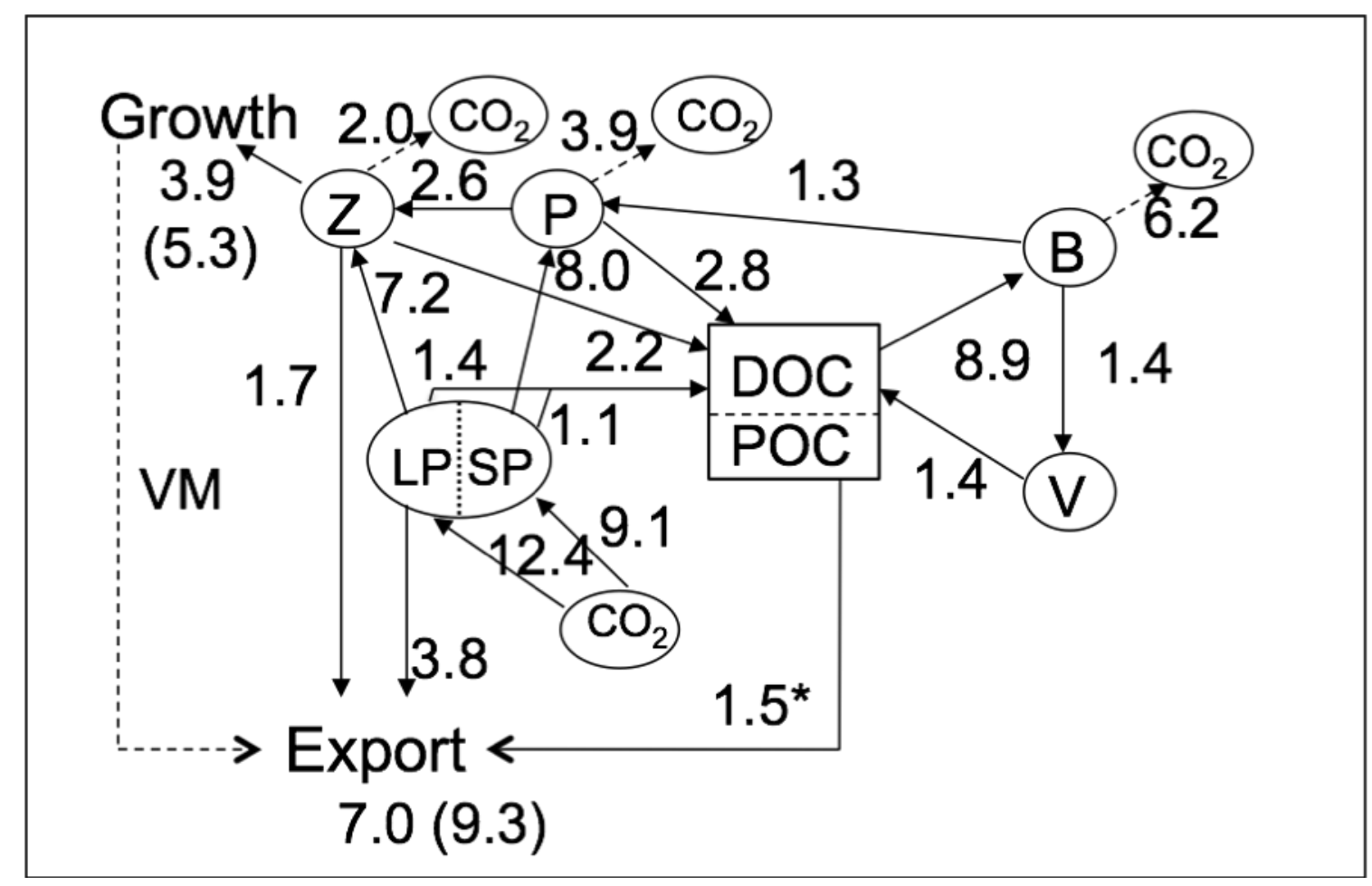

Fig. 11 Kudo et al. 